\title{
THE ALBERTA PROXY LEGISLATION: BORROWED VARIATIONS ON AN EIGHTEENTH CENTURY THEME
}

\author{
L. GETZ*
}

The author deals with the history of modern law as it relates to proxies. He deals with the form that they can take and the avenues of approach which are open to the various participants in a company. The present statutory requirements both in Alberta and elsewhere are reviewed and the author finally deals with the modern philosophy of investors and criticizes the piecemeal approach to reform which has not adequately achieved some of the purposes which should be served by ideal proxy legislation.

A good deal of hyperbole has surrounded the wave of company law reform that has recently swept across Canada. Thus, in introducing the first readings of the Ontario Business Corporations Bill ${ }^{1}$ and the Ontario Business Corporations Information Bill, ${ }^{2}$ Premier Robarts described them as "a shareholders' bill of rights and a directors' code of ethics." 3 They were, he said, "immensely progressive legislation"4 and "represent the dawn of a new era in our business community, for the corporations, shareholders and creditors". ${ }^{5}$ This rousing stuff comes as close as a speech on company law reform can, perhaps, to having the emotional appeal of "Quebec Libre" or "Uhuru". I propose in this article to describe one aspect of the new legislation - the provisions dealing with proxies and proxy solicitation-and then to enquire briefly to what extent they are capable of supporting the claims made.

\section{THE BACKGROUND}

The immediate source of the new legislation on proxies is the report, published in 1965, of the Ontario Attorney General's Committee on Securities Legislation." The Committee asserted that "in these days of large public companies with numerous shareholders, who as a rule do not have a voice in the management of the company, the proxy assumes major significance in the control of companies," tinued: ${ }^{8}$

In most cases, management of public companies sends out proxies in a form that invites shareholders who are unable to attend meetings in person to appoint only nominees of management to vote at meetings of shareholders. In this way there is a marked tendency for management to perpetuate itself in office. Further, proxies have been solicited to approve corporate action in cases where the shareholders have not been given sufficient information on which they could reasonably be expected to come to an informed decision.

The committee recommended legislative intervention to remedy these defects in the proxy system which, it observed, "may well turn out

- B.A., LL.B. (Capetown), LL.M. (London), LL.M. (Harvard). Assoclate Professor, Faculty of Law, University of British Columbia.

1 Bill 126. 1st Sess., 28th Legislature, Ontario, 1968.

2 Bill 125, 1st Sess., 28th Legislature. Ontario, 1968.

8 Debates of the Legislative Assembly, Ontario, May 17, 1968.

4 Id.

G The chalrman of the Committee was Mr. J. R. Kimber, Q.C. Report of the Ontario Attorney General's Committee on Securities Legislation in Ontario para. 602 (1965). Report of the Ontario Attorney General's Committee on Securities Legislation in Ontario, para. 6.02 (1965). 8 Id. 
to be the salvation of the modern corporate system." Before considering the legislation enacted in Alberta, which has in some degree adopted the Committee's proposals, ${ }^{10}$ it would be useful to fill out the Committee's strictures upon the state of the law at the time the Report was published.

At common law, shareholders in a business corporation had no right to vote by proxy. ${ }^{11}$ The common law rule was apparently derived from an earlier rule concerning the rights of members in the quasipublic medieval corporation" in which membership "was coupled with no pecuniary interest. The voting privilege was in the nature of a personal trust, committed to the discretion of the member as an individual, and hence not susceptible of exercise through delegation."13 Despite obvious differences in character and social function between the two types of corporation, no legal distinction was made. Indeed, one American court, when invited to differentiate, declared roundly that "the fact that it is a business corporation in no wise dispenses with the obligation for all members to assemble together, unless otherwise provided, for the exercise of a right to participate in the election of directors." 14

If there was to be a right to vote by proxy, special authority had to be found for it in the corporate constitution; ${ }^{15}$ as, in the memorandum jurisdictions at least, the rights created by the corporate constitution are contractual in character, ${ }^{16}$ there seemed no limits to the extent to which the right, if granted, could be contractually circumscribed. Frequently, for example, a shareholder could only appoint as his proxy ${ }^{17}$ another shareholder-a practice sanctioned by the "model" provisions of Table A. ${ }^{18}$ Since, especially in a company whose shares were widely

92 Loss, Securities Regulation 857 (2 ed. 1961), quoted with approval by the Kimber Report para. 6.04, supra, n. 7 .

10 Alberta Companies Act, R.S.A. 1955, c. 53, as amended by S.A. 1967, c. 9, ss. 128a-128h. Cf. also, British Columbla Companies Act, R.S.B.C. 1960, c. 67, as amended by S.B.C. 1967, c. 12. Ss. $166 \mathrm{~A}-166 \mathrm{H}$; Manitoba Companies Act. S.M. 1964' (2d Sess.). c. 3 , as amended by S.M. 1968, c. 9, Ss. 89-89F; Ontario Corporations Act, R.S.O. 1860, c. 71 , as amended by S.O. 1966, c. 28 , ss. $75-758$. Corresponding changes have been made in the various Securities Acts: Alberta Securities Act. S.A. 1967, c. 76, ss. 100-106 made in the various Securities Acts: Alberta Securities Act, S.A. 1967, c. 76, 5s. 100-106 British Columbia Securities Act, S.B.C. 1967, c. 45, ss. 98-105; Manitoba Securities
Act, S.M. 1968, c. 57, ss. 100-107; Ontario Securities Act, S.0. 1966, c. 142, ss. 100-107. In saskatchewan, the recommendations have been adopted in the securities Act, 1967 , c. 81, ss. 107-114. To avoid a multiplicity of citations, reference will be made to the Alberta Act in this article, except where there are significant variations in

11 the legislation of other provinces. (Ch.D.). McLaren $v$. Thomson [19i7] 2 Ch. 261 at 263 .

13 Walker v. Johnson (1900) 17 D.C. App. 14, cited by Axe, Corporate Proxies, (1942) 41 Mich. i. Rev. 38, at 39 .

14 Commonwealth ex. rel. Verree v. Bringhurst (1883) $103 \mathrm{~Pa}$. St. 134 at 138.

15 See, for example, Alta. Companies Act ss. 2 (q), (ff). Cf. Alta. Companies Act Table A, arts. 48-51. In the letters-patent jurisdictions the general pattern was that there was statutory authority for proxy voting in the absence of contrary provision in the by-laws. See, e.g. Canada Corporations Act, R.S.C. 1952, c. 33, s. 102 (b).

16 Alta. Companies Act $\mathrm{s}$. 28 (1). The position in the letters patent jurisdictions is unclear. See Beck, An Analysis of Foss v. Harbottle, in Ziegel (ed.), Studies in Canadian Company Law, (1967) 587-9; Interim Report of the Select Committee on Company Law, Province of Ontario [Lawrence Committee] paras. 8.1.2-2 (1967).

17 The term "proxy" is used in two different ways: sometimes, as here to denote a person who has authority to act for another, and sometimes to denote the instrument creating that authority. In Forester v. Newlands (West Griqualan) Diamond Mines creating that authority. In Forester v. Newlands (West Griqualan) Diamond Mines
Ltd. (1902) 18 T.L.R. 487. Kekewich J. described the former as the proper usage. The new lesislation has, however, adopted the latter: see, e.8. Alta. Companies Act ss. $128 \mathrm{a}$ (a) and (c). The Canada Corporations Act, R.S.C. 1952, c. 53, s. 103 (a) and the U.K. Companies Act, 1948 (11 \& 12 Geo. 6. c. 38) adopt the former. Nothing much turns on the usage-cf. Re English, Scottish \& Australian Chartered Bank [1893] Ch. 385- the important point beins that an agency relationship is created between the shareholder giving the authority and the nominee to whom it is given: Cousins v. International Brick Co. Ltd. [1931] $2 \mathrm{Ch}$. 90 at 95 per Luxmoore J.

Art. 50. But in Colonial Assurance Co. v. Smith (1912) 4 D.L.R. 814 at 818 it was held that unless the articles provided otherwise the nominee did not, at common law, have to be a shareholder. 
dispersed, the only other shareholders known to the persons giving the proxy were the directors from whom they received the forms, this device often had the effect of placing considerable voting power in the hands of the latter-in addition, of course, to preventing members from being represented by competent professional advisers.

Moreover, it was for the directors to determine what form the proxy instrument should take, and, therefore, what authority it conferred. ${ }^{10}$ In Re National Grocers Co. Ltd., ${ }^{20}$ for example, Roach J. described as "commonly used" a form of proxy in which the name of the management's nominee had already been filled in when received by the shareholder. The learned judge went on to remark that "very often unthinking shareholders more or less automatically sign these forms . . . and therefore the vote recorded under such circumstances cannot always be considered as reflecting the considered opinion of the absent shareholder."21 Yet, although the practice was condemned by one Canadian judge as "vicious"22 and described by another as "not good corporate practice," invalidate the proxy. ${ }^{24}$ Further, there was no general requirement that a two-way proxy form be used-that is, one worded in such a way as to permit the shareholder, through his nominee, to vote either for or against any proposal or group of related proposals. While some Stock Exchanges required this for listed companies, ${ }^{25}$ the model proxy form in Table A merely authorised the nominee to vote "for me and on my behalf," nominee, frequently a director, to vote as he thought fit and, if he thought fit, perhaps not to vote at all. ${ }^{27}$

19 Alta. Companies Act, Table A, art. 51.

20 [1938] 3 D.L.R. 106 (Ont. H.C.)

21 Id. at 112.

22 Re Dairy Corporation of Canada Ltd. [1934] 3 D.L.R. 347 at 349 per Middleton, J. A. The form of proxy in this case included the marginal note: "If you desire to nominate any other person your proxy, strike out the printed name and fill in the name of your nominee."

23 Spence, J. in Garvie v. Axmith (1962) 31 D.L.R. (2d) 65 at 77 (Ont. H.C.)

24 Re Langley's Ltd. [1938] 3 D.L.R. 230 (Ont.) Re English Scottish \& Australian Chartered Bank [1893] Ch. 385; but cf. McDougall v. Black Lake Asbestos \& Chrome Co. Ltd. (1920) 47 O.L.R. 328 which, however, probably turned on inadequate disclosure.

25 The Londion Stock Exchange has a requirement in its rules for 2-way proxies; Gower, Modern Company Law (2ed) at 442 . In Canada the situation varies. Neither the Montreal or Canadlan Stock Exchanges have any rules or regulations pertaining to proxies. Compantes on the Toronto Stock Exchange are subject to the Ontario Securities Act, S.O. 1966. c. 142 . Section 104 (b) of that Act provides for 2 way proxles and this would thus apply to the Toronto Exchange. The only Alberta Exchange the Calgary Stock Exchange, has adopted the requirements and definitions of the Alberta Securities Act, S.A. 1967 , c. 76. The provisions in section 104 (b) of that Act are identical to those in the same section of the Ontario Act providing for 2 way proxies.

26 Alta. Companies Act, Table A, art. 51.

27 There is some doubt whether a nominee is bound to act in accordance with the instructions given to him or, indeed, whether he is bound to cast his principal's votes at all. In Re Dorman, Long \& Co. [1943] Ch. 635 at 664, Maugham, J. suggested, obiter, that where directors get proxies they have "no option as to whether or not they will use them . . they are bound to use them. No discretion is vested in them." See also second Consolidated Trust v. Ceylon Amalgamated Estates [1943] 2 All E.R. 567 at 570 (Ch.D.). In Oliver v. Dalgleish [1963] 3 All E.R. 330 (Ch.D), a proxy holder who had received proxies instructing him to vote both for and against certain resolutions, cast the favourable but not the unfavourable votes. The Court found that the votes not cast would not have affected the result, but added, obiter, that the shareholders who had instructed him to vote against might have been able to complain of a breach of duty by him. Quaere, however, whether this would give rise to any action against the company: cf. defendant's whether this would give rise to any action against the company: cf. defendant' (Ch.D.) The British Insurance Association in its Mernorandum of Evidence to the Jenkins Committee, alleged that "it is possible for proxies to be suppressed or disallowed without the fact coming to the notice of the general body of shareholders." Minutes of Evidence. Appendix XXV, p. 631 to the Board of Trade Company Law Committee Cmnd. 1749, (1962) 
The articles customarily provided that proxy forms should be lodged by a specified time prior to the meeting to which they related. ${ }^{28}$ This, of course, was designed to give time for the proxies to be checked and verified. ${ }^{20}$ Most often, as in Table $A$, the time was fixed at 48 hours prior to the meeting, but it could be made longer-thus reducing the time available to members to decide upon their conduct and return the form ${ }^{30}$-or shorter, thus permitting management to solicit at the last minute if the verification process indicated that the vote was going against it. Morover, the Companies Acts generally provide that in the absence of contrary provision in the articles, a meeting other than one for the passing of a special resolution can be called on less than seven days' written notice. ${ }^{31}$ Clearly, if the articles authorise less than seven days' notice in these cases, the time available for the lodging of proxies might be exceedingly short. ${ }^{32}$ The United Kingdom Act now declares void any provision in the articles authorising shorter periods of notice than those statutorily specified, except in rigorously circumscribed circumstances. ${ }^{33}$

Other aspects of the old regime should be noticed. First, even where the company's constitution conferred the right to vote by proxy upon shareholders, there was no obligation upon the board, when sending out proxy forms at company expense, to supply them to all shareholders. In Wilson v. London, Midland \& Scottish Railway Co., ${ }^{34}$ for example, the directors sent out stamped proxy forms at company expense, in favour of themselves, to members owning shares to the value of $£ 2,500$ or more. To the others they sent only blank, unstamped forms. The court held that this was not improper, since the sole motive was to save expense and eliminate onerous clerical work otherwise involved in verifying the returns. The United Kingdom Act was amended, pursuant to a recommendation of the Cohen Committee in $1945,{ }^{35}$ so as to preclude this practice, ${ }^{30}$ but until the recent reforms it was still permissible in Canada. ${ }^{37}$

Second, the only obligation imposed upon those responsible for summoning company meetings was to give adequate notice, and, with one exception, ${ }^{38}$ the contents of the notice were left to be regulated by the articles of the company and by the rules of equity and the common

28 Alta. Companies Act, Table A, art. 50.

20 In Armstrong v. Landmark Corporation Ltd. (1966) 85 W.N. (Pt. 1) N.S.W. 239 . Street, J. held that a director is entitled to inspect the instruments of proxy lodged with the company for use at a meeting, but his right should be enforced in a manner that would not unreasonably interfere with the ordinary use of the proxies by the company and its officers-for example, to verify their accuracy.

30 See the Report of the Committee on Company Law Amendment (Cohen Report) Cmd. 6659, para. 126 (1945).

31 Alta. Companies Act, s. 127 (a).

82 But this would be most unusual.

83 U.K. Companies Act, 1948, s. 133.

34 [1940] Ch. 393 (C.A.), affirming [1940] Ch. 169.

35 Report of the Committee on Company Law Amendment (Cohen Report) Cmd. 6659, para. 132 (1945).

36 See now U.K. Companies Act, 1948, s. 136 (1).

37 See further, below pp. 26-27.

38 The definition of a special resolution requires that the meeting called to consider a special resolution must state the intention to propose the resolution as a special resolution: Alta. Companies Act, s. 2 (f); see also the definition of "extraordinary resolution" in Alta. Companies Act, s. 2 (q). Cf. MacConell v. Prill \& Co. [1916] 2 Ch. 57; Re North Victoria Deep Leads Gold Mines Ltd. (1934) 40 A.L.R. 221. But this requirement may be waived if all the shareholders are present and agree: Re Oxted Motor Co. [1921] 3 K.B. 32 . It is customary to set out the text of the resolution verbatim in the notice. 
law. ${ }^{39}$ It is true that in those cases in which judicial approval was essential to the validity of some corporate act, ${ }^{40}$ the courts as a matter of practice insisted upon full and fair disclosure, generally by means of an explanatory circular, ${ }^{41}$ of all relevant facts, ${ }^{12}$ but there was no statutory obligation to follow this procedure. ${ }^{43}$ Moreover, it has been held to be a part of the duty of directors to explain and defend to the membership, and where appropriate to solicit its support for, their conduct of the company's business, ${ }^{44}$ and also that it is proper to use company funds for the purpose; ${ }^{45}$ and it has also been held that the management is under no obligation, moral or legal, to circulate a contrary $\operatorname{case}^{48}$ or to include in the notice of meeting any reference to proposals other than those emanating from the management itself.47 This, of course, might be critical, for the general meeting cannot effectively do anything that is not fairly comprehended in the notice of meeting. ${ }^{48}$

The only way in which "non-management" shareholders could ensure that their proposals were brought before the general membership was by serving notice of requisition of meeting upon the directors,

39 Jenkins Report, supra, n. 27, para. 465. The articles commonly provide that "all business is deemed special that is transacted at an extraordinary meeting, and all that is transacted at an ordinary meeting with the exception of sanctioning a dividend, the consideration of the accounts, balance sheets and the ordinary reports of the directors and auditors, the election of directors and other officers, and the fixing of the remuneration of the auditors." Alta. Companies Act, Table A, art. 34 . Any meeting other than an annual Beneral meeting is an "extraordinary meeting." Any meeting other than an annual general meeting is an "extraordinary meeting. Alta. Compantes Act, Table A, art. 31. Cf. Austin Mining Co. v. Gemmell (1886) 10 O.R. 696 at 706; Re United Fuel Investment Ltd. (1962) 31 D.L.R. (2d) 331
at 341-2. In the case of a meeting called to consider special business, the "general nature" of that business must be described in the notice: Alta Companies Act, Table A, art. 33. For an example of the effect of failure to give adequate notice of "special business," see Charter Oil Co. Ltd. v. Beaumont (1967) 65 D.L.R. (2d) 112 (B.C.C.A.). No useful purpose is served by examing the cases on notice in detail. A succinct statement of their effect may be found in Gower, Modern Compan Law 437 (2 ed.) (1957). See also, Garvie v. Axmith, (1962) 31 D.L.R. (2d) 65.

10 E.g. compromises and arrangements under section 139 of the Alta. Companies Act, and under the Companies Creditors Arrangements Act. R.S.C. 1952, c. 54.

$\$ 1$ See for example, Re National Grocers, Co. $[1938] 3$ D.L.R. 106 (Ont. H.C.); R Braztlian Traction Light \& Power Co. [1947] 4 D.L.R. 736; Re N. Slayer \& Co. [1947] 2 D.L.R. 311; Re St. Lawrence Corpn. \& Myr. [1948] 2 D.L.R. 107.

12 The obligation to disclose is apparently considered espectally onerous where financial benefits to directors are involved: see, e.B. In re National Health Assn. (Galloway's Case) [1948] 2 W.W.R. 329 at 337 (B.C.S.C.).

43 Cf. In re Dorman, Lomg \& Co. [1934] Ch. 635 at 657,665

43 Cf. In re Dorman, Long \& Co. $[1934]$ Ch. 635 at 657, $665 . \quad$ (1908) 24 T.L.R. 623 (P.C.): Peel v. London \& Northwestern Railway Co. [1907] 1 Ch. 5 (C.A.); and see Bulfin v. Bebarfalds Ltd. (1938) 38 N.S.W.S.R. 423.

15 Id. But it was pointed out by Buckley L.J. in the Peel case that "cases often arise in which the board in power are anxious to maintain themselves in power to procure their own re-election, or to drive a policy not really in the interests of the company but for some private purpose of their own down the throats of the corporators at a general meeting, and in which they issue at the expense of the company circulars and proxy papers for the purpose of obtaining that object." The learned judge was careful to point out that the decision in peel would not justify such expenditures of corporate funds. How precisely the determination is justify such expenditures of corporate funds. How precisely the determination is to be made whether an expenditure is legitimate as being in defence of corporate
policies, or lllegitimate as being in defence of the directors personal position, was
not made clear. There are complicated questions of motive involved. cf. Hirsche not made clear. There are complicated questions of motive involved. cf. Hirsche
v. Sims [1894] A.C. 654; Mills v. Mills (1937) 60 C.L.R. 150 (H.C. Aust.); Madden v. Dimond (1905) 12 B.C.R. 80. Moreover, there remains the difficult question whether such expenditures, even if prima facie illegitimate, may be ratified by the general meeting. Compare the decision in cases such as Hogg $v$. Cramphorn [1966] 3 All E.R. 420 and Bamford v. Bamford [1968] 2 All E.R. 655 (Ch.D.), affd. on other grounds [1969] 1 All E.R. 969 (C.A.), on the analogous problem of the ratifiability of acts done to stave off a take-over bid. There has been some litigation on the subject of proxy fight expenses in the United States but the results are equally inconclusive. See generally. Aranow the United States, but the results are equally inconclusive. See generally. Aranow \& Einhorn,

16 Campbell v. Australian Mutual Provident Society (1908) 24 T.L.R. 623 at 624 (P.C.).

47 Gower, supra, n. 39, at 437.

48 Re Hampshire Land Co. [1896] 2 Ch. 473. Cf. McDougall v. Black Lake Asbestos \& Chrome Co. Ltd. (1920) 47 O.L.R. 328; and cf. Ball v. Metal Industries Ltd. [1957] S.C.R. 315 (requisitioned meeting). Perhaps the most important item of ordinary business at an annual general meeting is the election of directors, and the shareholders' right to propose nominees for office may be, and often is, limited by a provision in the articles requiring advance notice of nominations to be given to the company, together with written consent of the nominee. See, e.g. U.K. Companes Act, 1948, Table A, art 93. 
stating the objects for which they wished the meeting called. ${ }^{40}$ If the directors failed to comply, the requisitionists could themselves convene the meeting, ${ }^{30}$ and were entitled to be reimbursed for reasonable expenses incurred in so doing. ${ }^{51}$

The difficulties faced by shareholders wishing to communicate with their fellow members were noted by the Cohen Committee, ${ }^{52}$ and pursuant to its recommendations section 140 of the United Kingdom Act was introduced. This permits a certain proportion of members to call upon the company (a) to give notice of any proper resolution to be submitted to the annual general meeting, and (b) to circulate a statement not exceeding one thousand words relating to any matter referred to in any proposed resolution or to the business to be dealt with..$^{53}$ In certain situations the company may by court order be exempted from complying with such a demand. ${ }^{54}$ Otherwise, it must comply..$^{55}$

A similar provision was adopted in Ontario in 1953, and now appears as section 309 of the Ontario Act. ${ }^{\text {BD }}$ But it has not been adopted

19 Alta. Companies Act, s. 126 (1) \& (2). See also, Alta. Companies Act. Table A, art. 32. The minimum number of shareholders required for a valid requisition varies under the provincial statutes. In Alberta the number is fixed at one-twentieth of the voting shares: Alta. Companies Act $s$. 126 (1). There is authority that a single shareholder owning the requisite proportion of shares can validly requisition Single shareholder owning the requisite proportion of shares can validly requisition El Stalian Railway Construction C. Ltd. v. Hooper (1904) 48 Sol. J. 709: cf. Re El Sombrero Ltd. [1958] Ch. 900-but in Ingre v. Maxwell (1964) 44 D.L.R. (2d)
764 at 770, Verchere, J., cast doubt upon this. It is suggested that the doubt is unfounded. The provision of the Ontario Corporations Act requiring the requisition to be signed by shareholders holding one-tenth of the voting shares-Ont. Corporations Act, s. 308 (1)-was criticised by the Lawrence Committee as "obviously arbitrary and artificial," and the Committee proposed the substitution of an equally arbitrary and artfficial, though perhaps more sensible, figure of one one-twentieth, coupling it with a right given to a single member to requisition upon a court order, to be granted if the court is satisfied of his bona fides, and that "It is prima facie in the interests of the corporation or its shareholders" that a meeting be held. Report. supra, $n$. 2. This proposal is briefly discussed in Getz, Court Ordered Company Meetings, shortly to be published in The Conveyancer and Property Lawyer.

50 Alta. Companies Act, s. 126 (3). The power of the requisitionists, however, is given to them "as ministers of the company, and is not a proprietary right but is subject to the same control by the court as is the power given to directors to convene a meeting. Requisitionists must, therefore, exercise a proper discretion when convening such meetings." Adams v. Adhesives Ltd. (1932) 32 N.S.W.S.R. 398. See, as to directors, Cannon v. Trask (1875) L.R. 20 Eq. 669; Armstrong v. McGibbon (1906) 15 Que. K.B. 345. Cf. Cohen Report, supra, n. 30, para. 127.

61 Alta. Companies Act. s. 126 (6). The question whether non-management groups, if successful in a "policy" contest, can reimburse themselves from company funds has never been litigated in Canada or the United Kingdom, though it has been has never been litigated in Canada or the United Kingdom, though it has been United Stntes. See generally, 2 Loss, supra, n. 9 at 863-865; Aranow \& Einhorn, supra, n. 45 at $569-581$.

62 Cohen Report, supra, n. 30, para. 128.

53 U.K. Companies Act. 1948, s. 140 (1) (a) and (b). The section is poorly drafted -coetings" and that of s. 140 (1) (b) referring to "any general meeting."

54 Where the Court is satisfied that the rights conferred by the section are being abused "to secure needless publicity for defamatory matter." U.K. Companies Act, 1948,
s. 140 (5). See Re Harbour Lighterage Ltd. (1968) 87 W.N. (Pt. 1) N.S.W. 577.

65 The company must circulate the resolution or statement so far as practicable with the notice of meeting, or as soon as possible thereafter: U.K. Companies Act, 1948, s. 140 (3). The requisitionists must deposit a sum reasonably sufficient to meet the company's expenses-s. 140 (4) (b) - but this must be returned unless the meeting resolves otherwise: s. 140 (1).

56 The Ontario Act differs from the U.K. provision in that it limits the requisitionists' choice to call upon the company either to give notice of a resolution or to circulate a statement: s. 309 (1) (a). Of course, if under such a provision the requisitionists opt for the circulation of a resolution, they are free to send out a "camsitionists opt for, the circulation of a resolution, they are free to send out a "campaign document" at their own expense. Section 66 (1) of the Alberta Act permits remain open for inspection for not less than two hours per day during normal business hours, subject to such reasonable restrictions as the company may impose by ordinary resolution. Cf. Cooper v. Premier Trust Co. $[1945]$ I D.L.R. 376. In addition to the right to inspect, members have the right to obtain copies of the register upon payment of fees: Alta. Companies Act, s. 66 (2). The B.C. Companies Act contains similar provisions (s. 83) but provides also that a list of members may only be copled if an affidavit has been flled with the company that the list is required only for purposes connected with the company, and will be used for such purposes only: B.C. Companies Act $s$. 256 (2). This condition does not apply to barristers and solicitors, though the Registrar may require proof that they are not seeking a list for the purposes of evading the section: s. 256 (5). Section not seeking a list for the purposes of evading the section: s. 256 (5). Section
256 (2) of the B.C. Act is apparently designed to overcome the decisions in Mutter v. Eastern \& Midlands Rly. (1888) 38 Ch.D. 92 and Bloxam v. Metropolitan Rly. (1868) 3 Ch. App. 337, in which it was held that the fact that the person seeking inspection is hostile to the company is no defence to his legal right to inspect. 
elsewhere in Canada, and in any event, an English commentator has observed that it has proven of little value, first, because it produces no significant cost saving, and second for the tactical reason that if the company sends out the requisitionists' circular, the management has an opportunity to have the last word by issuing a statement in reply. ${ }^{57}$

\section{THE NEW LEGISLATION}

\section{(1) General-the right to vote by proxy.}

It is against this general background that the recent legislation on proxies and proxy solicitation must be seen. This legislation, as noted, is directly traceable to the Report of the Kimber Committee, which considered three main questions: "first, the contents of the form of proxy itself; second, the information which should be furnished by management or others to shareholders prior to a meeting of shareholders, if proxies are solicited, and the form in which such information should be presented; and third, whether or not forms of proxy should be required to be forwarded to shareholders at the time of calling shareholders' meetings." 58

In some provinces, however, among them Alberta, there was a preliminary question to settle: whether there should be a statutory right to vote by proxy, and if so, how extensive it should be. Alberta has followed Ontario's lead and conferred the right to vote by proxy upon all voting members of all companies. ${ }^{59}$ British Columbia, after a brief period of conformity, reasserted its uniqueness and demonstrated its talent for the unorthodox by conferring proxy rights only on voting members of public companies. ${ }^{60}$ All provinces permit a member to appoint any person as his nominee, whether or not that person is a member of the company. ${ }^{61}$ While the new legislation does not explicitly permit the nominee to speak at a meeting of shareholders, his right to do so seems implicit in the definition of a "proxy" as "a completed and executed form of proxy by means of which a shareholder has appointed a person as his nominee to attend and act for him and on his behalf at a meteing of shareholders."

More important than the right to speak, however, is the opportunity to make the member's vote effective. At common law the normal rule

57 Gower, supra, n. 39 at 441. Cf. Jenkins Report, supra, n. 27, para. 467. This may be an explanation for the fact that the section is little used, but it is hardly an argument against it.

58 Kimber Report, supra, n. 7, para. 6.09.

59 Alta. Companies Act, s. $128 \mathrm{c}$ (1). See also, Manitoba Companies Act, s. 89A (1); Ontario Corporations Act, s. $75 a$ (1).

60 B.C. Companies Act, s. 166B (1). The term "public company" has a special meaning in British Columbia, however, and includes a private company (in the traditional sense) that has fifteen or more shareholders: B.C. Companies Act. s. 38 (1). But the Registrar of Companies in British Columbia may exempt some companies falling into this category from compliance with all or any of the proxy provisions: B.C. Companies Act. See Getz, The Scope of the Proxy Provisions of the Companies Act, (1969) 27 The Advocate 209.

61 Alta. Companies Act. S. 128c (1); B.C. Companies Act, s. 166B (1). For the position prior to the new legislation, see supra, $n$. 18 and accompanying text. The importance of the new provision lies in the fact that a member can appoint a professional adviser as his proxy. Cf. Cohen Report, supra, n. 30, para. 133. The Cohen Committee thought it important that shareholders should be advised of their right to mittee thought it important that shareholders shouid be advised of their right to appoint non-members in the notice of meeting. Id. See now, U.K. Companies Act,
1948 , s. 136 (2). The Alberta legislation, while specifying the contents of the proxy form and requiring it to include a statement of the member's right to appoint his own nominee, does not require that the member be informed that he may appoint a non-member. See Alta. Companies Act, ss. 128 (f) and (g). It should be noted that Alta. Companies Act, s. 128c (1) nullifies the provisions of the Alta. Companies Act, Table A, art. 49, which restricted the member's right to the appointment of member-nominees only.

62 Alta. Companies Act, s. $128 \mathrm{a}$ (c). Ce. Jenkins Report, supra, n. 27, para. 463, and U.K. Companies Act, 1948, s. 136 . 
is that voting at any meeting takes place by a show of hands, in the absence of some statutory or bylaw provision to the contrary, ${ }^{63}$ and the balance of authority favours the view that on a show of hands "the shareholder holding a proxy votes only for himself and not for the absentee shareholder whose proxy he holds." ${ }^{64}$ The voting strength of the absentee member's shares only becomes effective on a poll, ${ }^{65}$ and the right to demand a poll is thus of considerable importance, especially since a shareholder may now appoint a non-member as his nominee. The Companies Acts provide that a poll may be demanded by one person for the time being entitled according to the articles to vote, or where some larger number, not in any case exceeding five, is prescribed by the articles, by that number of persons; ${ }^{\circ 6}$ but it is by no means clear that a non-member nominee may demand a poll under these provisions. ${ }^{67}$ The definition of a "proxy" cited above could be relied upon, but even this fails to put the point completely beyond doubt. $^{68}$

\section{(2) The concept of "solicitation".}

The basic pattern of regulation established by the new legislation has three aspects: first, it requires persons who "solicit" proxies to supply shareholders from whom they are solicited with forms of proxy meeting certain statutory specifications; and with additional information in the form of an "information circular"; second, it imposes penalties for non-compliance and for false or misleading statements made in any proxy material; and third it requires the filing of proxy material with the Securities Commission.

The critical concept in the new statutory scheme is that of "solicitation." The words "solicit" and "solicitation" are defined to "include (i) any request for a proxy whether or not accompanied by or included in a form of proxy; (ii) any request to execute or not to execute a form of proxy or to revoke a proxy; (iii) the sending or

63 Re Horbury Bridge, Coal, Iron \& Waggon Co. (1879) 11 Ch.D. 109; Re Calorific Engine \& Siren Fog Signals Co. Ltd. (1885) 72 L.T.N.S. 846.

64 McKenna v. Spooner Oils Ltd. [1934] 1 W.W.R. 225 (Alta. A.D.); Ernest v. Loma G.M. Ltd. [1897] 1 Ch. 1 (C.A.). There is some doubt whether a vote by show of hands is an essential pre-requisite to a demand for a poll. In Carruth $v$. Imperial Chemical Industries Ltd. [1937| A.C. 707 at 775. Lord Blanesburgh expressed the view that there can be no valid demand for a poll unless there has been a
valid show of hands. It seems, however, that the matter is one of interpretation valid show of hands. It seems, however, that the matter is one of interpretation of the articles, and in Holmes v. Lord Keyes $[1959\}$ Ch. 199 at 212 (C.A.). Jenkins, with Alta. Companies Act, Table A, art. 40, the poll may validly be taken without a show of hands.

65 Alta. Companies Act, s. 128 (3).

08 Alta. Companies Act, s. 128 (2). Cf. Alta. Companies Act, Table A, art. 40.

67 There is some authority for the view that these provisions require that the demandant be a member present in person. See, e.g. Queen v. Government Stock Investment Co. (1878) 3 Q.B.D. 443; McCurdy v. Gorrie (1913) 32 N.Z.L.R. 769. In Re Haven G.M. Co. (1882) 20 Ch.D. 151 at 157, Bacon, V-C thought that a proxy could not be regarded as "authority to take so important a step as to demand a poll." But regarded as "authority to take so important a step as to

68 Compare the wording of the definition in Alta. Companies Act, 128a (c) with that of the proxy in Re Haven G.M. Co. (1882) Ch.D. 151. There are some grounds for thinking that the point may be academic, at least in some cases. Flrst, section $128 \mathrm{~g}$ although designed to eliminate "unnecessary balloting" in cases where only a small percentage of votes is to be cast against some proposal-Kimber Report, supra, n. 7, para. 6.16-could be taken as meaning that a poll is to be the normal procedure, whether or not there is a demand. If so, it conflicts with $s$. 128 (3), though, being a later enactment, will probably prevail. Second, there is authority that, at least where the articles authorize the chairman to demand a poll he must do so if he has reason to believe that the vote on a poll would differ from that on a show has reason to believe that the vote on a poll would differ from that on a show Estates Ltd. [1943] 2 All E.R. 567. It is the duty of the chairman to ascertain the Sense of the meeting: Re Lemay Ltd. (1924) 26 O.W.N. 443; Bleuchel \& Smith v. Prefrabricated Building it. [1945], 2 D.L.R. 725 at 729; Henderson v. Bank of Australasia (1890) 45 Ch.D. 330; National Dwelling Society v. Sykes [1894] 3 Ch. 159 . 
delivery of a form of proxy or other communication to a shareholder under circumstances reasonably calculated to result in the procurement, withholding or revocation of a proxy; and (iv) the sending or delivery of a form of proxy to a shareholder pursuant to section 128d," but not to exclude " $(v)$ the sending or delivery of a form of proxy to a shareholder in response to an unsolicited request made by him or on his behalf; or (vi) the performance by any person of ministerial acts or professional services on behalf of a person soliciting a proxy."

This definition is borrowed almost verbatim from Regulation 14a-170 promulgated by the United States Securities and Exchange Commission pursuant to the Securities and Exchange Act of $1934,{ }^{71}$ and much of the law that has developed under that regulation will be helpful in resolving questions of interpretation under the Canadian legislation.

The S.E.C. Regulations apply to both written and oral communications, and the Commission requires that solicitation material in the form of speeches and radio and television scripts must be filed. ${ }^{72}$ The Canadian provisions, while not explicit on this point are, it is submitted, equally as extensive. There is nothing in the definition of "solicitation" to justify restricting the term to written communications; indeed, the penalty provisions refer to "solicitations . . . by means of a form of proxy, information circular, or other communication". ${ }^{73}$ While these words might arguably be construed ejusdem generis with the other words in the section, there is no warrant for such a restrictive interpretation.

Most of the clauses in the definition of "solicitation" are fairly straightforward. Two of them, however, call for some comment. First, clause (iv), read together with section $128 \mathrm{~d}$ of the Act, has the effect of declaring that the management of a company solicits proxies whenever it sends out a notice of meeting. ${ }^{74}$ In making the recommendation upon which this provision is based, the Kimber Committee stated that it would ensure that shareholders receive adequate information, and that "the costs involved to companies in preparing and furnishing proxies and information circulars will be justified by wider dissemination of corporate information which will thus be made available to the public."75

Perhaps the most important part of the definition is clause (iii), which gives rise to the difficult question of when a solicitation commences. In Securities and Exchange Commission v. Okin, ${ }^{70}$ a shareholder sent a letter to his co-members asking them not to sign proxies favouring the management of the company, or to revoke any such proxies that they may already have given. He did not, however, ask that proxies be executed in his favour. The S.E.C. sought to enjoin distribution of the letter on the ground that it was false and misleading. The Commission contended that though the letter was not

00 Alta. Companies Act, s. 128a (d).

70 Quoted in Aranow \& Einhorn, supra, n. 45 at 100.

71 U.S.C. S. $78 \mathrm{n}$ (1964).

2 Rule 14a-6 (g). Moreover, Rule 14a-9, dealing with false and misleading statements, explicitly refers to "written or oral communications." Aranow \& Einhorn, supra, n. 45 at $100-101$.

73 Alta. Companies Act, s. 128 e (4).

74 Quaere whether this applies to requisitionists who call a meeting upon default of the directors to do so? Cf. supra, n. 50 .

$75 \mathrm{~K}$ Imber Report, supra, n. 9, para. 6.24.

76132 F. $2 d 784$ (2d Cir. 1943). 
itself a solicitation, the defendant intended to follow it up by actually soliciting proxies for himself. Judge Learned Hand held that the Commission's regulations extended to any writings "which are part of a continuous plan ending in solicitation and which prepare the way for its success."77 Any other view would leave the way open to evasion: "one need only spread the misinformation adequately before beginning to solicit."78

The specific conduct in question in Okin-communicating to procure the revocation or withdrawal of proxies-is now specifically covered by clause (iii). But the problem of determining whether a particular communication constitutes a solicitation remains. Some of the difficulties are illustrated in two cases, both of which arose out of the battle for control of the Rock Island Railway in 1963.

In Brown v. Chicago, Rock Island \& Pacific Railroad Co., ${ }^{79}$ the management representatives of the Union Pacific and Rock Island railway companies had agreed, on May 13,1963, to recommend a merger plan to their respective boards of directors. On June 22, the Chicago Railroad company made an offer to buy a controlling shareholding in Rock Island. Despite the fact that on June 27 the board of Union Pacific and Rock Island had approved and executed the merger, Chicago on July 23 began proceedings before the Interstate Commerce Commission for approval of its proposed acquisition of Rock Island shares. On July 25, Union Pacific petitioned the I.C.C. to dismiss Chicago's application on the ground that the transaction was contrary to the public interest (a matter which the Commission was bound to consider and upon which it might receive evidence from interested members of the public). The following day Union Pacific placed an advertisement in 45 newspapers across the United States, containing an analysis of the two contending plans, and exhorting Rock Island shareholders "to examine this offer carefully." The advertisement was addressed to shareholders, employees, consumers and commuters serviced by the railroads. A shareholder in Rock Island complained that this was a proxy solicitation. The court rejected the contention, and held that, being published concurrently with the petition to dismiss the Chicago application, the advertisement was merely an attempt to motivate the public interest against Chicago's application. It was published mainly in citjes served by Rock Island and Union Pacific, no proxies were solicited, nor was there any statement that proxies would be solicited in the future, and the advertisements were not "reasonably calculated to result in the procurement" of proxies.

To complete the merger, approval of the Rock Island shareholders was required, and the proceedings to obtain this gave rise to the second case, Union Pacific Railroad Co. v. Chicago and Northwestern Railroad Co. ${ }^{80}$ Some months before the meeting to consider the matter was called, a lawyer wrote to eight Rock Island shareholders suggesting the formation of a committee to oppose the merger. Chicago agreed to assist this committee financially, to supply it with information, and

77 Id. at 786.

i8 Id. Learned Hand, J.'s view was adopted in Security \& Exchange Commission v. Topping 85 F. Supp. 63 (S.D.N.Y. 1964). See also, Studebaker Corporation v. Gittlin 360 F. $2 \mathrm{~d} 692$ (2d Clr. 1966).

79328 F. 2d 122 (7th Cir. 1964).
80226 F. Supp 400 (D.C. Ill. 1964). 
to indemnify it against any liabilities that might arise from the use of this information. After the meeting had been duly summoned, proxy solicitation by all parties began. Among the material distributed was a report by a brokerage firm, based upon information supplied by Chicago, which was sent to the firm's customers. Some copies of the report were sent by Chicago to Rock Island shareholders and to people in a position to advise them. Union Pacific protested to the S.E.C. about this material, which had not been filed with the Commission, and requested that action be taken. The S.E.C. declined to act, and Union Pacific sought a court order restraining the holding of the Rock Island meeting. The court held that the brokerage firm's report, being cast in the form of advice to the Rock Island shareholders, and concluding that the Chicago offer was more attractive than the Union Pacific proposal, was a communication reasonably calculated to result in the procurement, withholding or revocation of a proxy.

The wording of clause (iii) of the statutory definition is literally broad enough to cover disinterested discussion and analysis of corporate affairs in the financial press, for the statute is not in terms limited to the activities of interested parties or participants. It is true that the court in Union Pacific Railroad Co. v. Chicago \& Northwestern Railroad Co., was apparently influenced by a sense that the brokerage firm whose report was circulated was not truly independent of the dispute, and the Securities and Exchange Commission takes the view that its rules "apply only to the proxy solicitor or 'participants' in a proxy solicitation, and not to outsiders who editorially comment on the contest." ${ }^{21}$ On the other hand, while to subject truly independent press comment to the burden of the legislation might be destructive of one of the objects of legislation of this kind, and hence counterproductive, there is no question but that it may fall within the words of the definition.

A similar problem arises in relation to the activities of brokerdealers and investment advisers who distribute information and advice to clients. The statutory definition does exclude "the sending or delivery of a form of proxy to a member in response to an unsolicited request made by him or on his behalf," this principle ought to extend to cover the advice given by a broker or adviser to his client in response to an unsolicited request. This is certainly the view taken by the S.E.C. in the United States, ${ }^{83}$ and that is doubtless authoritative there. But it should be borne in mind that the legislation is not clear, and that the Canadian provincial Securities Commissions do not have the general interpretative power over the statutory provisions that is enjoyed by the S.E.C. in respect of its regulations. It may well be that costly litigation will be required to resolve many of these difficulties of interpretation.

(3) Exclusions and exemptions.

The exclusions from the definition of "solicitation" contained in clauses (v) and (vi) of the statutory provision do not call for com-

81 Aranow \& Einhorn, supra. n. 45 at 105; 2 Loss, supra, n. 9 at 873-4.

82 Alta. Companies Act, s. $128 \mathrm{a}$ (d) (v).

83 Securities Exchange Act Release No. 7208, Jan. 7, 1964, reproduced in full in Aranow \& Einhorn, supra, n. 45, Appendix E. 
ment; but the exemptions-that is, solicitations not subject to the Act-are extremely important.

(a) Private companies and public companies with fewer than fifteen shareholders. ${ }^{84}$

While fairly straightforward, this is perhaps the most important of all the exemptions, for it has the effect of relieving the overwhelming majority of companies otherwise subject to the solicitation provisions from compliance. The purpose of the exemption as drafted is not entirely clear, however, for there does not seem to be any obvious principle upon which a distinction is made between a public company with 16 shareholders and a private company with the same number of shareholders. It may be that the intention was to draw a distinction between companies offering shares to the public and other companies, and that a public company with fifteen or more shares is, in effect, deemed to be making a public offer. If so, it would have been much simpler to have said this in the statute. ${ }^{85}$

(b) Non-management solicitations of not more than fifteen shareholders. ${ }^{\text {s6 }}$

This exemption is apparently designed to facilitate the organization of groups opposed to management, without the danger that their activities will become known before they are fully organized. ${ }^{87}$ It may also reflect a conviction that non-management solicitations of fewer than fifteen shareholders do not raise a problem that is worthy of legislative attention. While the term "management" is not defined, ${ }^{88}$ the courts will doubtless take a common-sense view of the problem. ${ }^{89}$ Two points should be briefly made. First, in determining whether or not more than fifteen shareholders have been solicited, joint shareholders are treated as one; ${ }^{00}$ second, the requirements of the exemption cannot be evaded by members of a non-management group individually soliciting fourteen members each, or by organizing a solicitation in "chainletter" fashion. ${ }^{01}$

(c) Solicitations pursuant to section 79 of the Securities Act. $^{92}$

This exemption is designed to take account of the practice whereby brokers hold shares in "street name," ${ }^{03}$ so that the identity of the

84 Alta. Companies Act, s. 128b (1). The proxy form and information clrcular need only be sent to shareholders entitled to vote, who alone are to be taken into account in considering whether the number of 15 shareholders is exceeded. Thus, where, although there were more than 15 shareholders, fewer than 15 were entitled to vote, the others being preferred shareholders only entitled to vote in certain circumstances not present, it was held that the mandatory solicitation provisions did not apply: not present, it was held that the mandatory

85 Cf. Ontario Bill 125, 1st Sess., 28th Legislature, 1968, s. 107 (1)

80 Alta. Companies Act, s. $128 \mathrm{e}$ (2) (a).

87 Aranow \& Einhorn, supra, n. 45 at 110-111. The authors suggest that this exemption is especially valuable in permitting the formation of stockholders protectlve committees. Cf. the comments of Gower, supra, $n$. 39 at 441 , on section 140 of the U.K. Companies Act, 1948.

88 Cf. Charlebois v. Bienvenue (1967) 64 D.L.R. (2d) 683 at 690 (Ont. H.C.) where, however, the Court refrained from attempting a definition.

$80 \mathrm{Cf}$. Berle \& Means, Modern Corporation and Private Property (rev. ed. 1967) 196 who define "management" as "that body of men who, in law, have formally who define management as that boding of mer the corporate business and assets. assumed the duties of exercing a legal title of some sort." And see id. at 112. Alta. Companies Act, s. 128e (2) (a).

91 Ce. Aranow \& Einhorn, supra, n. 45 at 111

02 Alta. Companies Act, s. $128 \mathrm{e}$ (2) (b).

93 "A "street form" certificate . . is a certificate registered in the name of a stock exchange member and duly endorsed or a certificate registered in the name of any other person or firm and duly endorsed with endorsement guaranteed by a stock exchange member." Lawrence Report, supra, n. 16, para. 6.1.3. n. 72. The advantase 
beneficial owner is not disclosed on the register of members. Broadly speaking, the Securities Act provides ${ }^{04}$ that a broker, broker-dealer or investment dealer registered under the Act who is the registered owner of shares of which he is not the beneficial owner may not vote those shares unless he transmits to the beneficial owner (i) the notice of meeting, financial statements, information circular and other proxy material, apart from the proxy form itself, without expense to the beneficial owner; ${ }^{95}$ and (ii) a written request for voting instructions which states that unless such instructions are received at least 24 hours prior to the time fixed by the company for the lodging of proxies, or, if no such time has been fixed, then 24 hours before the time for holding the meeting, the broker may give the proxy or vote the shares himself and in his discretion.96

If these conditions are complied with, the communication between the broker and his client, though technically a solicitation within the statutory definition, will be exempt. Two points should be noted. First, the exemption does not cover every case of a communication by a nominee shareholder to the beneficial owner concerning the execution of proxies. It is confined to communications emanating from someone who is a "registrant" under the Securities Act.97 If the registered owner is not a registrant, the exemption will not apply, ${ }^{08}$ though some other exemption may well be available.

Second, reference has already been made to the position of brokers and advisers giving investment advice to clients in the ordinary course of business. ${ }^{99}$ Their position is perhaps clearer where they transmit the proxy literature but, instead of merely sending a neutral request for voting instructions, they attempt to persuade or offer advice to the beneficial owner as to how they should vote or what instructions they should return to the broker. In these circumstances, the exemption would be lost. This, at least, is the position taken by the Securities and Exchange Commission under a comparable, though more clearly worded provision in the United States. ${ }^{100}$ The S.E.C. has stated its view ${ }^{101}$ that

material distributed during a period while proxy solicitation is in progress, which comments upon the issues to be voted on or which suggests how the stockholders should vote, would constitute soliciting material. Similarly, material originating with the broker which is sent along with the proxy material which the broker is distributing on behalf of somebody else would almost

of street certificates is that they are freely transferable, and come close to being negotlable instruments, as a matter of brokerage practice if not of law. Cf. Melanson v. McCleave (1957) 11 D.L.R. (2d) 579 (N.S.); Aitken v. Gardiner \& Watson [1956] O.R. 589.

94 Alberta Securities Act, S.A. 1967, c. 76, s. 79.

95 Alta. Securities Act, S. 79 (3) requires the company to provide the broker with sufficient copies for transmission. Quaere where the broker is solfcited otherwise than by management.

96 The broker may not vote shares of which he is the registered owner where he does not know the Identity of the beneficial owner: Alta. Securities Act. S. 79 (2). Where the beneficial owner is known and gives instructions, they must be followed
-5 . 79 (4) but fallure to do so does not affect the validity of the meeting or any proceeding taken at it: s. 79 (6). In Murphy v. Lindzon et al \& Conigo Mines Ltd. proceeding taken at it: s. 79 (6). In Murphy v. Lindzon et al \& Conigo Mines Ltd.
$[1969] 1$ O.R. 631, 3 D.L.R. (3d) 423 Stewart. J. held that the corresponding provision of the Ontario Securities Act did not authorize the Chairman of the meeting to reject votes in the absence of proof that the provisions of the Act had been complied with But "if proof by a beneficial owner (or on such person's behalf) were shown at the meeting that compliance with section 79 had not been made then of course the President could decide to reject such vote." Id.

97 The class of persons required to register is defined in section 6 (1) of the Securities Act.

8 Cf. Generslly, Baillie, The Protection of the Investor in Ontario, (1965) 8 Can. Pub. Admin. 172 at 266-68.

89 See above, p. 28.

100 Reg. 14a-2b.

101 In an opinion of Its general counsel-Sec. Exch. Act. Rel. No. 7208, Jan. 7, 1964, quoted in Aranow \& Einhorn, supra, n. 45, Apendix $E$. 
always constitute a solicitation because of the circumstances under which it comes into the hands of the security holder.

Elsewhere in the same opinion the Commission, quoting an earlier opinion, ${ }^{102}$ points out that the exemption is based upon the assumption that the banker or broker forwarding the material is acting in a ministerial capacity and is not making an independent solicitation from the beneficial owner. Thus, "the exemption will be lost if the firm does not act in an impartial manner, for example, if it transmits the material of one side promptly and delays transmission of the material of the other side, or passes on some but not all soliciting literature."103

(d) Solicitations by beneficial owners in respect of their own shares. ${ }^{104}$

The most obvious case to which this exemption applies is that of the unregistered transferee of shares who has not succeeded in obtaining registration in the books of the company before the register of members is closed prior to the meeting. ${ }^{105}$ In the ordinary course of events the equitable interest in specific ascertained shares passes immediately upon the conclusion of the contract of sale. ${ }^{106}$ Consequently, the unregistered transferee will be able to solicit the seller's proxy. It will be readily apparent that without this exemption a take-over bidder who has not managed to obtain registration of transfers of shares he has acquired, would be in considerable difficulty. Under this exemption, provided that he does not solicit until after the beneficial interest has passed, ${ }^{107}$ he will be protected in marshalling proxies.

This exemption also protects the beneficial owner of shares held by a nominee where the former wishes to obtain a proxy so as to be able to attend the meeting himself, or to appoint someone other than the registered holder to represent him. As has been noted, ${ }^{108}$ The Securities Act requires a "registrant" to solicit instructions from the beneficial owners of shares of which he is the registered owner, under the protection of an exemption. The present exemption is not confined to cases where the registered owner is a "registrant" under the Securities Act.

\section{(e) Judicial exemption.}

Section 128b (2) of the Alberta Companies Act permits a court "if it is satisfied that in the circumstances of the particular case there

102 Sec. Exch. Act. Rel. No. 4668, Jan. 31, 1952.

103 Walsh \& Levine v. Peoria \& Eastern Railway Co. 222 F. Supp. 516 (S.D.N.Y. 1963).

104 Alta. Companies Act, s. $128 \mathrm{e}$ (2) (c).

105 The Company may close the register of members for a period not exceeding 30 days per year, by giving notice of its intention to do so in a newspaper circulating in the district of its head office: Alta. Companies Act, s. 67. And see Alta. Companies Act, Table A, art. 17.

100 Hawks V. McArthur [1951] 1 All E.R. 22 at 26. Cf. Gaby v. Federal Packaging \& Partition Co. Ltd. (1965) 52 D.L.R. (2d) 295, affd. sub. nom. Gordon v. Gaby (1966) 57 D.L.R. (2d) 1 (S.C.C.) Taylor v. Borger (1964) 44 D.L.R. (2d) 605 (Alta. A.D.). In the case of a Stock Exchange sale, however, which is normally of unascertainable shares, the beneficial interest will not arise until a transfer has been executed by the seller, whlch identifles the shares by number: Re London, Hamburg \& Continental Exchange Bank (1867) 2 Ch App. 431 at 438 . Cf. Re C. A. Macdonald \&

o7 Cf. Mills v. Sarjem Corporation, 133 F. Supp. 753 (D.N.J. 1955). Quaere the position of the bidder, on the facts, in Lyle \& Scott Ltd. v. Scott's Trustees [1959] A.C. 763. But it has been held that where an option to purchase shares is granted on terms that it shall be exercised by a specified date, the relationship of buyer and seller is only created upon payment of the purchase price, not upon the exercise of the option. Hare v. Nicoll [1966] 1 All E.R. 285 at 290, per Willmer, L.J. Presumably, therefore, the equitable interest does not pass and the optionee could not take advantage of the exemption to solicit the optionor's proxies until the price has been pald.

108 See above, pp. 29-31. 
is adequate justification for so doing," to exempt any person otherwise subject to the solicitation provisions from compliance with them. ${ }^{109}$ This provision is based upon a recommendation of the Kimber Committee, ${ }^{110}$ which, beyond saying that "there may be circumstances in which it is not appropriate or useful to require the mandatory solicitation of proxies or the furnishing of an information circular at the time of solicitation of proxies,"111 offers no guidance as to what these circumstances might be.

(4) The proxy form where proxies are solicited.

Every proxy form issued in connection with a meeting of a company subject to the new rules must meet certain minimum requirements, ${ }^{112}$ and, when proxies are solicited, additional conditions must be fulfilled. ${ }^{118}$

The proxy form must indicate in bold-face type whether or not the proxy is solicited by or on behalf of the management of the company. ${ }^{114}$ Presumably, if the solicitation is not made by or on behalf of management, it is sufficient merely to make a statement to this effect, without going further and identifying by whom or on whose behalf the solicitation is made. Detailed information as to the identity of those on whose behalf the proxy is solicited must be included in the information circular in any case. ${ }^{115}$

A statement must be included in the form of proxy as to the member's right to appoint his own nominee, ${ }^{116}$ and a place provided for and the manner indicated in which this is to be done. ${ }^{117}$ The date and place of the meeting to which the proxy relates must be indicated, since the Act provides that no proxy shall confer authority to vote at any meeting other than the meeting specified in the notice of meeting, or any adjournment thereof. ${ }^{118}$ The proxy itself must be dated, ${ }^{110}$ and the authority conferred by it-in any event limited to a single meeting and proper adjournments-automatically lapses upon the expiry of a year from that date. ${ }^{120}$

109 The application for exemption may be made by "any interested person." In Re Frontier Acceptance Corp." supra, n. 84, it was suggested obiter, that the corporation is an "interested person." Cf generally in the exemption provisions in the B.C. Companies Act, 8. 38A (1) and (6). See generally Getz, supra, n. 60 .

110 Report, supra, n. 7, para. 6.25.

111 Id.

112 Alta. Campanies Act, s. $128 \mathrm{c}$.

113 Alta. Companies Act, 8. $128 f$.

114 Alta. Companies Act, s. 128 (a) (1).

115 Alta. Companies Act, 128 (f).

116 Alta Companies Act, $128 f$ (t).

17 Alta. Companies Act, s. $128 \mathrm{f}$ (g). And see supra, n. 61. It is Benerally desirable to name several proxles in the alternative in case one or more is unable to attend. In Pitt v. Hadrill (1917) 55 Que. S.C. 166, the member signed a proxy appointing several named persons, not in the alternative, "or any one of them with powers of substitution." It was held that this authority was joint and several, and that the votes subject to the proxy could be cast pursuant to a decision of the majority of those named. Ignoring the opposition of the other If there is an equal division of oplnion among several nominees, the shareholder may lose his vote: Nesbitt, Thomson \& Co. v. McColl Frontenac Oil Co. (1938) 43 Que. P.R. 138.

118 Alta. Companies Act, s. $128 \mathrm{f}$ (d) (ii). The addition of the words "or any adjournment thereof" is probably unnecessary, since an adjourned meeting is merely a continuation of the meeting adjourned: Jackson v. Hamlyn [1953] Ch. 577; McLaren v. Thomson [1917] 2 Ch. 261. Without fresh notice an adjourned meeting cannot transact any business other than that left uncompleted at the original meeting: Christopher v. Coxon (1883) 4 O.R. 672; Robert Batcheller \& Sons Ltd. v. Batcheller [1945] Ch. 169. But under Alta. Companles Act, Table A. art. 39, fresh whether new busiven

110 Alta Companies Act, s. $128 \mathrm{c}$ (3).

120 Alta. Companies Act, s. $128 \mathrm{c}$ (2). The date will also be important in cases of voteswitching, since the latest proxy will revolke all earlier ones. See further, as to revocation, below pp. 36-39. 


\section{Electioneering}

Shareholders must be provided in the form with an "opportunity to specify that the shares registered in his name shall be voted by the nominee in favour of or against, in accordance with the choice of the person, each matter or group of related matters identified therein or in the information circular as intended to be acted upon, other than the election of directors and the appointment of auditors." ${ }^{121}$ The Securities and Exchange Commission regulations upon which this provision is based"122 requires that the proxy form shall identify "clearly and impartially" the matters to be voted upon, and these words have been used by the commission as a means of controlling electioneering and other hortatory practices. The S.E.C.'s statement of policy on electioneering123 makes it clear that "arguments or recommendations as to the merit of proposals, emphasis upon the management's position beyond the mere statement of the fact that management favours or opposes a proposal, the use of arrows or any other visual device designed to direct the shareholders' attention to the place on the proxy for voting one way and away from the place for voting the contrary, and the switching of boxes in order to procure the result desired by the management," are contrary to its rules.

Some of these practices-for example, "box-switching" and visual devices-might be caught by the common law rules about "tricky" circulars. ${ }^{124}$ On the other hand, "arguments or recommendations as to the merit of proposals" would not, per se, be proscribed. ${ }^{12 s}$ Indeed, as has been noted, there is authority for the view that the directors have an obligation to solicit support for their conduct of the corporate business, ${ }^{128}$ and it is possible that the more stringent attitude of the S.E.C. would not be followed in Canada. It is pertinent to note, moreover, that there is nothing in the regulations prescribing the content of information circulars to indicate that these documents should include only the contents specified, ${ }^{127}$ and it is possible that electioneering in the circular would stand a better chance of passing muster than in the proxy form itself. ${ }^{28}$

\section{Elections}

The provision of an opportunity to direct that the nominee vote either for or against a particular proposal does not extend to the election

121 Alta. Companies Act, s. 1281 (b).

122 Rule 14a-4 (a) and 14a-4 (b). Alta. Regulations 227, 1967, Form 3, Item 10, requires that the substance of each ... matter, or related group of matters, should be briefly described ... in sufficient detail to permit shareholders to form a reasoned judgment concerning any such matter.

123 Sec. Exch. Act. Rel No. 4185, Nov. 5, 1948, quoted in full in Aranow \& Einhorn, supra, $\mathrm{n} .45$ at $168-9$.

124 E.g. Garvie v. Axmith, supra, n. 23; Tiessen v. Henderson [1899] 1. Ch. 861. Cf. also Alta. Companies Act 8. 128 e (4).

125 In Peter's American Delicacy Co. Ltd. v. Heath (1969) C.L.R. 457 at 489 (H.C.A.) Latham C.J.A., in dismissing certain objections to a circular on the ground that it was misleading, described them as merely "objections which put the case against the proposals of the directors."

126 See above, pp. 21-23.

127 The regulations merely state that "an information circular shall contain the information prescribed." Alta. Regs. 227, 1967, s. 6 (1).

$128 \mathrm{Cf}$. the suggestion made to the Cohen Committee that two-way proxies have the effect of instituting a system of voting by referendum, where voting precedes discussion Report, supra, n. 30, para 132. 
of directors or the appointment of auditors. ${ }^{129}$ This is an entirely satisfactory arrangement where the only matter to be acted upon at the meeting is the election of directors, for the member can simply decline to return the proxy if he does not wish to vote for the candidates whom he is asked to support. But if there are other matters to be voted upon, it may be unsatisfactory if he wishes to vote on those matters, but not to support the management nominees for office, and there is no proxy contest presenting him with an electoral alternative. In such a case, he is forced to vote for the management candidates, or forfeit his franchise completely. The S.E.C. regulations cope with this problem by requiring that where proposals are to be voted on in addition to elections to office, facilities must be provided for the member to withhold his proxy in respect of the elections. ${ }^{130}$

Section $128 \mathrm{f}$ (d) (i) provides that no proxy shall confer authority to vote for the election of any director unless a bona fide nominee is named, either in the proxy form or in the information circular. This is designed to ensure disclosure of the identity of candidates for office, and its effect is seen in Charlebois v. Bienvenue. ${ }^{132}$ The plaintiffs had been directors of a company which was controlled by the first defendant and his associates. Prior to the annual meeting in July 1967, proxies were solicited and an information circular sent out pursuant to the mandatory solicitation provisions of the Ontario Corporations Act. ${ }^{132}$ The proxies stated that they were being solicited by management, and, since directors were to be elected, the information circular included the names of all the members of the existing directorate, who were candidates for re-election, together with other required information about them. At the meeting, however, the first defendant and his associates did not support the plaintiffs, but elected four other persons, not named, in their place. The plaintiffs thereupon sought interlocutory injunctions, inter alia, to restrain the board purportedly elected at the meeting from acting as such, or from interfering with the board as previously constituted. The court held that the failure to name and give information about the four new directors was a failure to comply with the Act, and granted the injunctions. ${ }^{133}$ This result seems clearly consistent with the general purpose of the legislation. The effect of the decision is that where proxies are solicited in respect of an election of directors, the group soliciting them is limited to supporting or, subject to any duty to vote proxies, ${ }^{134}$ withholding its support from, its own nominees. It may not nominate new candidates about whom the requisite disclosure has not been made. But any group that does not

120 Alta. Companies Act, s. $128 f$ (b).

130 Regs. $14 a-4$ (b) (2) If the member does not execute the proxy so as to withhold authority to vote in an election, the proxy will be deemed to grant such authority provided the form indicates this in bold face type. The proxy form sent out for Annual General Meeting of Husky Oil Ltd. in April 1969 included spaces enabling members to grant or withold authority to vote for the management nominees for election and also included the bold-face type statement called for by the Securitios \& Exchange Commission regulations. This is doubtless good corporate practice, but is not required by Alberta law.

181 (1967) 64 D.L.R. (2d) 683.

132 Corresponding to Alta. Companles Acts, 128d.

183 The decision is considered more fully below, p. 39 .

134 Supta, n. 27, 
solicit proxies is apparently free to nominate without advance notification $^{135}$ of the candidates' names at any annual general meeting. ${ }^{138}$

Two further points should be noted in connection with elections. First, "if the shareholders or any class of shareholders have the right to elect a specified number of directors or have cumulative or similar voting rights," the information circular must include a statement of those rights and describe the conditions precedent to their exercise. ${ }^{137}$ Second, it is curious that, despite the elaborate provision made for elections, it has not been thought desirable to permit a shareholder some choice other than simply voting for or against a slate of nominees for office. This is done in a number of jurisdictions by requiring that in public companies "a motion for the appointment of two or more persons as directors of the company by a single resolution shall not be made, unless a resolution that it shall be so made has first been agreed to by the meeting without any vote being given against it."138 Of course, the Kimber Committee Report does not deal with this question, since it was beyond the Committee's terms of reference. That, presumably, is why no consideration appears to have been given to it in the Alberta Act: an illustration of the dangers of piecemeal company law reform.

\section{Discretionary authority}

If the member fails to indicate how he wishes to vote on the matter identified in the proxy form or information circular, the nominee may use the member's votes in his discretion, provided that the form or circular states in bold face type how it is intended to cast them. ${ }^{130} \mathrm{~A}$ similar discretion is conferred upon the nominee "with respect to amendments or variations to matters identified in the notice of meeting and other matters which may properly come before the meeting," provided that the proxy solicitor is not aware that any such amendments, variations or other matters are to be presented for action at the meeting,

185 The articles almost invariably provide that election of directors at an annual general meeting is not special business requiring special notice. Alta. Companies Act, Table A. art. 34. See Choppington Collieries Ltd. v. Johnson [1944] 1 All E.R. 762. But see Re French Tubeless Tyre Co. [1900] 1 Ch. 408.

180 Alta. Companies Act, Table A, arts. 31, 34. Cf. Charter Oil Co. Ltd. v. Beaumont [1967] 65 D.L.R. (2d) 112 (B.C.C A.).

187 Alta. Regulations 227, 67 (1967), Form 3, Item 4 (c). Cumulative voting is not required by any of the provincial companies legislation. It is expressly permitted by 5.64 of the Ontario Corporations Act, and seems impliedly authorized by the definition of "special rights or restrictions" in $\mathbf{s}$. 2 of the B.C. Companies Act. Cf. Alta. Companies Act, s. 78 (1). None of the statutes prohibit cumulative voting. Cf. Alta. Companies Act, s. 78 (1). None of the statutes prohibit cumulative voting.
Cf. Lawrence Report, supra, n. 16, ch. vili. Aranow \& Einhorn, supra, $n$. 45, point Cf. Lawrence Report, supra, n. 16, ch. vili. Aranow \& Elinhorn, supra, n. 45, point
out (at 166) that where cumulative voting is allowed, a soliciting group "may wish to out (at 166) that where cumulative voting is allowed, a soliciting group "may wish to [information circular]. Such action would appear to be a deviation from a provision in the form of proxy that the proxy agents are authorized to vote for the nominees (all of them) named in a certain [information circular]." The authors suggest that it is advisable in this case for the proxy form to state that the proxy votes will be cast "cumulatively for any or all of the nominees." Id. But cf. 'Charlebois v. Bienvenue (1967 64 D.L.R. (2d) 683 .

138 U.K. Companies Act, 1948, s. 183 (1): South African Companies Act., No. 46 of 1926 (as amended), s. 69 bis (1). These provisions are based upon a recommendation of the Cohen Committee: Cohen Report, supra, n. 30, p. 84. The South African provision goes further than that in the United Kingdom, and has given rise to some difficulties. See Schachat v. Transvaal Credit \& Savings Bank Ltd. (1963) (4) S.A. 523, and Aitchison v. Dench (1964) (2) S.A. 515, noted in [1963] Ann. Surv. S.A. Law, 350, and [1964] Ann. Surv. S.A. Law 239, respectively.

130 Alta. Companies Act, s. $128 \mathrm{f}$ (b). This provision has been criticized in the United States on the grounds that it confers an unfair advantage on management. The arguments are summarised in 2 Loss, supra, n. 9, at 882-3. See also Bayne, Caplin, Fmerson \& Latcham. Proxy Regulation and the Rule Making Process: The 1954 Amendments, (1954) 40 Va. L. Rev. 387 at $414-6$. 
and a statement is included in the proxy form or circular that such discretionary authority is being conferred. ${ }^{140}$

\section{Execution}

Every proxy must be executed by the member giving it, or by his attorney duly authorized in writing. ${ }^{141}$ Ordinarily, execution by the member himself creates no problem, though difficulties may arise where a member splits his proxies among two nominees, and there is a variance between the signatures, or where he gives proxies to different people in respect of the same shares.

\section{Corporate proxies}

The new legislation specifically permits a corporate shareholder to vote by proxy. ${ }^{142}$ The person nominated as a corporate proxy must be carefully distinguished from an authorized corporate representative. A corporation may, by resolution of its board of directors, authorize someone to act as its representative at any meeting. ${ }^{148}$ The person so authorized "is entitled to exercise the same powers on behalf of the company he represents as if he were an individual shareholder of that other company." 144 But a duly authorized corporate representative is not a proxy. His position is that he is treated as if he were the registered shareholder, and he is not confined, as he would be if he were a proxy nominee, to voting only on a poll, but may vote on a show of hands. A vote cast by a corporate representative is thus treated as the equivalent of a vote given "personally" by the corporation shareholder.

A corporate proxy must be executed under the common seal of the corporatoin or by a duly authorized officer or attorney. ${ }^{145}$ All that is required for the formal validity of the proxy is that it should be executed by the corporation shareholder in accordance with the provisions of its own constitution. ${ }^{148}$

\section{Revocability of the proxy}

The regulations governing the content of information circulars require a statement whether or not the member has a right to revoke

140 Alta. Companies Act, s. $128 f$ (c). This provision does not affect the range of amendments or varlations that may be validly considered at a meeting. So far as ordinary resolutions are concerned, the general principle seems to be that any amendimen coming within the scope of the notice of meeting is permissible provided it does not commit the company to anything more burdensome than did the original resolution: Re Secord Standard Rovalties Itd. (1930) 66 O.L.R 228 at 298-299;Torbock v Lord Westbury [1902] $2 \mathrm{Ch} 871$. Henderson $v$ Bank of A ustralasia (1890) 45 Ch 330 t 46 . 33o at based upon the wording of the definition of a special resolution as one of which notice "specifying the intention to propose a resolution as a special resolution' has been given, and the corresponding definition of an extraordinary resolution: Alta. Companies Act, ss. 2 (ff) and (q). Cf. the authorities referred to above, and MacConell v. E. Prill \& Co. Ltd. [1916] 2 Ch. 57. In Re Second Standard Royalties Ltd. (1930) 66 O.L.R. 288 at 229, Orde J.A. suggested a further limitation precludins any amendment which may possibly affect the rights of shareholder inter se so as to benefit some at the expense of others. See generally. Palmer's Company Precedents, (17 ed. 1956) vol. 1, p. 862-3.

141 Alta. Companies Act, s. $128 \mathrm{c}$ (2).

142 Alta. Companies Act. $128 \mathrm{c}$ (1)-adopting the common law rule: see Re Indian Zoedone Co. (1884) 26 Ch.D. 70.

143 Alta. Companies Act, s. 135. The right to vote under this section depends upon whether a valid resolution has in fact been passed, not upon whether adequ-te evidence of the passage of the resolution has been tendered at the meeting: Cotonial Gold Reef Lta. v. Free State Rand Ltd. [1914] 1 Ch. 382 . Cf. Murphy v. Lindzon et al. * Conign Mines Ltd. (1969) 1 O.R. 631, 3 D.L.R. (3d) 423; Remfrey v. Aloha Shangri-La Atlas Cruises Pty. Ltd. [1968] Qd. L.R. (W.N.) 99.

144 Alta. Companies Act, s. 135.

145 Alta. Companies Act, s. 128c (2).

146 Cf. Johnson v. Hall (1957) 10 D.i.R. (2d) 243 (B.C.). 
his proxy and, if so, whether that right is in any way limited. ${ }^{147}$ Most corporate constitutions include provisions dealing with revocation, generally along the lines of Table A, article 73 of the United Kingdom Act. $^{148}$ In so far as the machinery of revocation is concerned, the matter is now dealt with by section 128c (4) of the Alberta Companies Act, which provides that a proxy may be revoked by instrument in writing ... deposited either at the registered office of the company at any time up to and including the last business day preceding the day of the meeting, or any adjournment thereof, at which the proxy is to be used or with the chairman of such meeting on the day of the meeting, or adjournment thereof, and upon either of such deposits the proxy is revoked."140 This provision presumably renders void any attempt in the articles to restrict the time in which notice of revocation may be lodged.

The usual form of article also authorizes the company to treat a vote given by proxy as valid despite revocation, unless the company has been notified of the revocation in the manner prescribed by the articles. Such a provision, which is designed for the protection of the company, ${ }^{150}$ is not affected by the new legislation. The machinery of section 128c (4) is however, expressly stated to be "in addition to revocation in any other manner permitted by law," but the meaning of this phrase is not clear. It could be taken to cover a situation where the articles do not include a protective clause; in this case, it might be argued that a revocation communicated to the nominee is effective against the company. Alternatively, it might be interpreted as covering those cases such as, perhaps, insanity and death, in which it is suggested that the authority of the agent is, as a matter of law, terminated immediately without the need for any further communication on behalf of the principal. ${ }^{151}$ But it is submitted that even in these cases the company ought to be able to rely upon any protective provision in its articles.

It also seems to be the law that a member may attend and vote in person despite the fact that he has given a proxy and not revoked it. As Luxmoore J. put it in Cousins v. International Brick Co. Ltd., ${ }^{152}$ "the right of the shareholder to vote in person must . . . in the absence of any special contract between himself and the company expressly precluding the right to vote in person, where a proxy has been validly

147 Alta. Regulations 227/67, (1867), Form 3, Item 1.

148 "A vote given in accordance with the terms of an instrument of proxy shall be valid notwithstanding the previous death or insanity of the principal or revocation of the proxy or of the authority under which the proxy was executed, or the transfer of the shares in respect of which the proxy is given, provided that no intimation in writing of such death, insanity, revocation or transfer as aforesaid shall have been received by the Company at the office before the commencement of the meeting or adjourned meeting at which the proxy is used." There is no counterpart to this provision in Table $A$ of the Alberta Act.

140 In Spiller v. Mayo (Rhodesia) Development Co. (1908) Ltd. [1926] W.N. 78, the articles required notice of revocation to have been recelved at the company's office "before the meeting." It was held that a revocation received after the meeting had commenced but before a poll had been taken was ineffective. The effect of the new commenced but before a poll had been taken was ineffective. The effect of the new legislation on this decision is unclear. The statutory provision could be taken to
allow revocation at any time on the day of the meeting. but it would be clearly allow revocation at any time on the day of the meeting, but it would be clearly of many companies requiring notice of revocation to be received by the company not later than a specified time prior to the meeting, are rendered void by the new statutory provision.

150 In Cousins v. International Brick Co. Ltd. [1931] 2 Ch. 90 at 96, Luxmore J. described the purpose of such a provision-e.g. Table A, art. 73, of the United Kingdom Actas "to protect the company in case the proxy is effectively used, from any liability to enquire whether it has in fact been revoked or not."

151 Ce. Pennington, Company Law 521 (2 ed. 1967).

162 [1931] $2 \mathrm{Ch} .90$ at 95 . 
given, be paramount to the right of the proxy to vote." But personal attendance and voting in these circumstances is not, apparently, revocation. "When a shareholder appears at the meeting and says he prefers to vote in person, he is not revoking the proxy previously given, but doing an act which does away with the necessity of the proxy ever being exercised at all."153 The consequence of this view is that where a number of items appear on the agenda and a member who has given a proxy attends the meeting and elects to cast his vote personally on some of them, the nominee may cast the proxy votes on the others. ${ }^{154}$

\section{Irrevocable proxies}

At common law it is possible for an agency relationship to be created irrevocably or for a specified period of time. The agent's authority will be irrevocable where it is an "authority coupled with an interest" or "security power," 155 that is, one given for valuable consideration or to protect some interest of the donee. An irrevocable proxy can be similarly created, though what constitutes a sufficient interest for the purpose may given rise to difficulties. But a proxy given to an unregistered transferee or an equitable mortgagee of shares is clearly included. ${ }^{150}$ In such a case, the principal's right to revoke will be limited, and the donee of the power will be able to obtain an injunction to prevent the nominee from voting the shares. ${ }^{157}$

A proxy may also be created for a limited period of time, and as between nominee and member will be irrevocable until that time has elapsed. ${ }^{158}$ In either event, however, the new legislation limits the

153 Cousins v. International Brick Co. Ltd. [1931] 2 Ch. 90 at 103 . See also Ansett v. Butler Air Transport Ltd. (No. 2), (1958) W.N. (N.S.W.) 306, discussed extensively in Herron, Proxy Voting at Corporate Meetings, (1958) 32 Austr. L.J. 249. The in Herron, Proxy Voting at Corporate Meetings, (1958) 32 Austr. L.J. 249. The is outstanding, the powers of the proxy holder are suspended, except in the case of a proxy coupled with an interest, which states that on its face, if the person executing the proxy is present at the meeting and elects to vote in person." Cal. Corp. Code, para. 2228 (emphasis supplled). But cf. Holman v. Clegg (Ch.D.unreported, noted in (1957) 101 Sol. J. 216) where the defendant, who had a substantial interest in the company, gave a proxy in the usual form to two accountants, together with a document in which she stated that in consideration of their agreeing to act as controllers of the company, she had given a proxy which she undertook "not to withdraw for two years," or until such time as they might deem the company's finances to be satisfactory. A dispute arose and the defendant claimed to exercise the voting rights. Vaisey $j$. held that this would be a "withdrawal" of the proxy, and granted an injunction restraining her from voting at the meeting.

164 "If a shareholder attends a meeting at which two resolutions are proposed and he votes on the first, the right of his proxy to vote on the second remains. unimpaired, because since he has not revoked his proxy it must remain in force in respect of any other act to which it relates. Further, since the option to vote personally or by proxy may be exercised right up to the moment when the vote is taken, it must be an option which is exercisable on each occasion a vote is is taken, it must be an option which is exercisable on each occasion a vote is taken." Per Myers, J. in

155 Restatement, Agency, Para. 138. See, e.g. Mitchell v. Sykes (1883) 4 O.R. 501; Richardson v. McClary (1906) 16 Man. R. 74.

156 Pennington, supra, n. 151, at 521n. The New York Business Corporation Law of 1966 provides, in s. 69 (f), that "a proxy which is entitled "Irrevocable proxy" and which states that it is irrevocable, is irrevocable when it is held by any of the following or a nominee of any of the following: (1) A pledge; (2) A person who has purchased or agreed to purchase the shares; (3) A creditor or creditors of the corporation who extend or continue to extend credit to the corporation in consideration of the proxy if the proxy states that it was given in consideration of such extension or continuation of credit, the amount thereof, and the name of the person extending or continuing credit; (4) A person who has contracted to perform services as an officer of the corporation, if a proxy is required by the contract of employment, if the proxy states that it was given in consideration of such contract of employment, the name of the employee and the period of employment contracted for; (5) A person designated by or under an agreement under parasraph (a) of section 620." Section 620 (a) deals with shareholders' voting

157 Cf Knight v. Bulkeley (1958) 27 L.J. Ch. 592- sed quaere as to the effect of the rationale of Cousins v. International Brick Co. Ltd. [1931] 2 Ch. 90, upon this proposition.

168 Cf. Holman v. Glegg (Ch.D.-unreported, noted in (1957) 101 Sol. J. 216). 
authority conferred by a proxy to a period of one year from its date. ${ }^{150}$

\section{(5) The information circular.}

Every person soliciting proxies must, unless the solicitation is exempt, send to each member of the company a document described as an "information circular."180 In case of failure to do so that person, and, in the case of failure by a company, every director or officer who authorized, permitted or acquiesced therein, is guilty of an offence carrying a maximum penalty, on summary conviction, of one thousand dollars. ${ }^{101}$ The circular must be sent, in the case of a solicitation by management, "either as an appendix to or as a separate document accompanying the notice of meeting," 1162 and in the case of any other solicitation, "concurrently with or prior thereto." 163

The detailed contents of the information circular are prescribed in regulations issued by the Lieutenant-Governor in Council under the authority of the Companies Act. ${ }^{104}$ These regulations contain detailed instructions as to the form in which the information must be provided, ${ }^{165}$ subject to an overriding requirement that it be "clearly presented."166 In addition to the specific information that must be disclosed in the circular, the regulations provide that "if action is to be taken on any matter to be submitted to the meeting of shareholders other than the approval of financial statements, the substance of each such matter, or group of related matters, should be briefly described ... in sufficient detail to permit shareholders to form a reasoned judgment concerning any such matter." 167

The circular must include details with respect to the revocability of the proxy, ${ }^{103}$ the identity of the persons by whom or on whose behalf the solicitation is made, its cost, and, if it is made otherwise than by mail, the method and personnel employed, ${ }^{100}$ any material interest of the persons making the solicitation, directors, nominees for election as directors, senior officers and any associates of any of these persons, in any matter to be acted upon at the meeting other than the election of

\footnotetext{
159 Alta. Companies Act, s. $128 \mathrm{c}$ (2).

160 Alta. Companies Act, s. 128e (1).

161 Alta. Companies Act, s. $128 \mathrm{e}$ (3).

102 Alta. Companies Act, s. 128e (1) (a).

103 Alta. Companies Act, s. 128e (1) (b)

164 Alta. Regulations $227 / 67$, (1967)

1 A5 Alta. Regulations 227/67, (1967), ss. 7-9.

160 Alta. Regulations $227 / 67$, (1967), s. 7 (1). In Richland v. Crandall 262 F. Supp. 538, at 544 (S.D.N.Y. 1967) it was stated that "corporations are not required to address their stockholders as if they were children in kindergarten." See also, Shvetz $v$ their stockholders as if they were children in kindergarten." See also, Shvetz v.
Industrial Rayon Corporation 212 F. Supp. 308 (S.D.N.Y. 1960). In Brundage v. Industrial Rayon Corporation 212 F. Supp. 308 (S.D.N.Y. 1960). In Brundage v. circular "could well have been so prepared as to have been more readily understandable by the ordinary stockholder" was countered by an argument that the information given was necessarily involved and technical, and would not mislead a person trained in reading complex financial statements. The court, after referring to a comment in the New York Times that "investors are too often misled by so-called "generally accepted accounting principles." urged that additional reguso-called generally accepted accounting principles, urged that additional regulations should be promulgated by the s.E.C. "to afford a greater measure of protection to the ordinary stockholder who, though he may have no expertise reasonably expects to be able to understand proxy statements as well as other corporate communications." Id. at 598. Cf. Kimber Report, supra, n. 7, at paras. 4.01-4.06, on the importance of presenting information in a form which is understandable by the investing public. See also the views of the Kimber Committee on "narrative prospectuses." Report, supra, n. 7, paras. 5.09-5.10. Generally on the subject of disclosure, see Gower, supra, n. 39 at 415-6, 429-30. And see Atiyah. Thoughts on Company Law Philosophy, 8 The Lawyer 15 at 16-18 (1965).

167 Alta. Regulations 227/67, (1967), Form 3, Item 10. The test is substantially that propounded by Spence, J. in Garvie v. Axmith (1962) 31 D.L.R. (2d) 65 at 86-7 as to the contents of a notice of meeting.

168 Alta. Regulations 227/67, (1967), Form 3, Item 1. See above, pp. 26-29.

160 Alta. Regulations 227/67, (1967), Form 3, Item 2.
} 
directors or appointment of auditors; ${ }^{170}$ the ownership of and rights attached to the company's equity securities; ${ }^{171}$ if directors are to be elected, the identity, occupation and past experience of every nominee for election and every continuing director, together with details of their ownership of shares in the company or any subsidiary and, if any such person and his associates are the beneficial owners of more than ten per cent of the voting rights attached to all the company's voting shares, or those of a subsidiary, details as to the associates and their holdings. ${ }^{172}$ If directors are to be elected, or any action is to be taken with respect to any bonus or profitsharing, pension or retirement plan, or a stock option scheme other than a general rights issue, and any director, nominee for election as such or senior officer is to participate in any such plan, details must be given as to various forms of remuneration paid by the company to these persons, and of the plan generally. ${ }^{173}$ The circular must also disclose details of any direct or indirect material interest of any director, senior officer, nominee for election as a director, "insider, and any associate or affiliate of any of these persons in any transaction or proposed transaction which has materially affected or will materially affect the company or any subsidiary. ${ }^{174}$ If auditors are to be appointed, information must be given about them, ${ }^{175}$ and if the management of the company or a subsidiary is carried on by someone other than its directors or senior officers, details must be disclosed of any management contract. ${ }^{176}$ Finally, as has been noted, sufficient information must be given about any matter to be submitted to the meeting to enable shareholders to form a reasoned judgment about it. ${ }^{177}$

It would be tedious to analyze the details required to be disclosed, item by item. What is important is to notice the potentially vast range of persons and companies about whom information may have to be given in the circular. In addition to directors and nominees for election as directors, information must be given about those who are responsible for the solicitation. ${ }^{178}$ In the case of a solicitation otherwise than on behalf of management, the regulations require disclosure about "any member of a committee or group that solicits proxies, and any person whether or not named as a member who, acting alone or with one or more other persons, directly or indirectly, takes the initiative or engages in organizing, directing or financing any such committee or group,"170 and any person who contributes more than two hundred and fifty dollars to financing a non-management solicitation. ${ }^{180}$ Disclosure is required about "senior officers"181 and their associates, ${ }^{182}$ and an "as-

\footnotetext{
170 Id., Item 3.

171 Id., Item 4.

172 Id., Item 5.

178 Id., Item 6

174 Id., Item 7.

175 Id., Item 8.

170 Id., Item 9.

177 Id., Item 10.

178 Id., Item 3 .

180 Id, Item 3 (b), Instruction 1 (a)

181 The term "senior officer" is defined for "Insider trading" purposes in section $88 \mathrm{a}$

(1) (b), and includes the five highest paid employees. That definition is adopted for the purposes of the regulations: Alta. Regulations, 227/67, (1967), s. 2 (2). It is based upon a comparable definition in S.D.C. Regulation 16-3b-2, which has given based upon a comparable definition in S.5.C. Regulation 16-3b-2, which has given rise to some interpretative difficulties in the United States. See 2 Loss, suma, n.99 (1958) $12 \mathrm{Sw}$. L.J. 147 at 157-159.

182 Alta Resulations, 227, 67, (1967), Item 3 (d), Item 5 (a) (v), Item 7 (d).
} 
sociate" of a person includes"183 "any company of which the person beneficially owns, directly or indirectly, equity shares carrying more than ten per centum of the voting rights attached to all equity shares of the company for the time being outstanding." ${ }^{184}$ The term also includes "any relative or spouse of the person or any relative of the spouse who, in any such case, has the same home as the person."185

(6) Enforcement of the proxy legislation.

(a) Offences and penalties.

Section 128d (2) makes it an offence for the management of a company subject to the mandatory solicitation requirements of section $128 \mathrm{~d}$ (1) ${ }^{186}$ to give notice of meeting without sending to each shareholder entitled to vote a form of proxy complying with the Act. The company, and every director or officer who authorized, permitted or acquiesced in the failure is liable, upon summary conviction, to a fine not exceeding one thousand dollars. Section 128e (3) penalizes any solicitation of proxies that is not accompanied by an information circular complying with the Regulations. Any person who commits the offence and, in the case of a company, any director, or officer who authorized, permitted or acquiesced in the commission of the offence is liable upon summary conviction to a fine not exceeding one thousand dollars. Section 128e (4) makes it an offence to solicit proxies by means of any communication "that contains an untrue statement of a material fact or omits to state a material fact necessary in order to make any statement contained therein not misleading in the light of the circumstances in which it was made." Upon summary conviction of the offence, a person and, in the case of a company, every director or officer who authorized, permitted or acquiesced in its commission, is liable to a fine not exceeding one thousand dollars. But section 128e (5) provides that no offence is committed under section 128e (4) if the untruth of any statement or the fact of any omission "was not known to the person who effected the solicitation and in the exercise of reasonable diligence could not have been known to such person."187

(b) Administrative supervision and enforcement.

(i) Filing of documents with the Securities Commission.

The Kimber Committee decided against recommending that the information circular be required to be filed with or receivable by any governmental agency before it is forwarded to shareholders. ${ }^{188}$ The regulations issued pursuant to the Alberta Companies Act require, however, that every person that distributes an information circular to which the provisions of the Companies Act apply, "and that is in respect of a meeting of the shareholders of a company which is a

188 Alta. Companies Act, s. 88a (1) (b).

184 Alta. Companies Act, s. 88a (1) (b) (1).

185 Alta. Companies Act, s. $88 \mathrm{a}$ (1) (b) (ili). The regulations also call for information about the interests in material transactions of "affillates" of certain specifled categories of person: Item 7 (iv). If, as seems clear, the term is used with the same meaning as in the "insider trading" legislation and the accounting provisions, same meaning as in the "insider trading" legislation and the accounting provisions, this requirement cannot be complied with under the proxy provisions, for as there case of a corporate director, it is impossible for any person to have an affiliate within the meaning of the Act.

180 See above, pp. 26-27. As to exemptions, see above pp. 28-29.

187 Is it too much to expect that legislative draftsmen will use consistent language? Why the sudden use of "effected" rather than "by whom or on whose behalf the solicitation is made."

188 Report, supra, n. 7, para. 6.26. 
corporation" within the meaning of section 100 (a) (i) or (ii) of the Alberta Securities Act, file solicitation material with the Alberta Securities Commission within five days after the date such material is first mailed by the person distributing it. ${ }^{189}$ A "corporation" thus defined is a company whose shares are listed and posted for trading on a stock exchange in Alberta that is recognized by the Securities Commission, ${ }^{100}$ or a company which offers shares to the public in Alberta through the medium of a prospectus filed with the Commission. ${ }^{191}$

(ii) Administrative supervision by the Commission.

Section 106 (1) of the Alberta Securities Act authorizes the Commission to decline to issue a receipt for a prospectus relating to any proposed offer of shares to the public by any company, until the company and such of its directors and officers as the Commission may designate deliver satisfactory undertakings to comply with such of the proxy provisions of the Securities Act as the Commission may direct. Alberta companies are not ordinarily subject to the proxy provisions of the Securities Act, being specifically excluded by section 100 (a) (iii); but if they offer shares to the public in Alberta, or are listed and posted for trading on a stock exchange in the province, they become subject to the prospectus requirements of that Act. Since no public offering of shares can lawfully be made without a receipt for a prospectus filed with the Securities Commission,, ${ }^{122}$ the power to extract undertakings as to compliance with the proxy provisions as a condition of the issuance of a receipt, effectively gives the Commission a basis for administrative surveillance over proxy solicitation. But this power does not extend to non-management groups, which, apart from their obligation to file solicitation material with the Commission after it has been sent, are entirely free from any administrative controls.

\section{(iii) Judicial enforcement by the Commission-injunctions.}

The Alberta Companies Act is silent on the question whether the Securities Commission may obtain a court order to enjoin continued or threatened violation of the proxy provisions of that Act. But section 147 (1) of the Securities Act provides that the Commission

(a) upon the commencement of or after the investigation of a person or company under section 21 or $23^{193}$ or

(b) where it has made a direction, decision, order or ruling suspending or cancelling the registration of a person or company or affecting the right of a person or company to trade in securities, or

(c) where
(i) criminal proceedings, or
(ii) proceedings in respect of a violation of this Act
have been instituted against a person or company and, in the opinion of

189 Alta. Regulations $227 / 67$, (1967), s. 10 (1) (b).

100 Alta. Securities Act, S.A. 1967, c. 76. As of July 14, 1969 the Calgary Stock Exchange advised that there were 112 companies listed on the exchange. The Calgary Exchange is the only one recognized in Alberta by the Securities Commission.

101 Alta. Securities Act, $s$. 100 (a) (i), read together with $S_{\text {. }} 2$ (1) 16. As of July 8, 1969, there were 182 companies with prospectuses filed with the Securities Commission according to that body. The total of 'corporations' as defined by the Act would thus appear to be 294. However the Commission advises that this figure might in fact represent some duplication-that is companies with registered prospectuses and also listed on the Exhange.

192 Alta Securities Act, s. 35.

$193 \mathrm{~S}$. 21 authorizes the Commission to order an investigation to be held if its appears probable that any of the provisions of the Act or regulations have been contravened, or any offence under the Criminal Code in connection with a trade in vecurities has been committed. Section 23 authorlzes the Attorney General to order an investigation to be made. Cf. International Claim Brokers Ltd. v. Kinsey \& Attorney General of British Columbia (1966) 55 W.W.R. 672 (B.C.C.A): 
the Commission, are connected with or arise out of any security or any trade therein or out of any business conducted by that person or company involving securities,

may by originating notice of motion apply to the Supreme Court of Alberta for an injunction to restrain that person or company from doing any act that is similar to or related to any act or matter that is the subject of any investigation, direction, decision, order, ruling or proceedings referred to in clause (a), (b), or (c).

If the court is satisfied that the person or company to be restrained "is apparently continuing to do or may in future do the act complained of"104 and that "it is in the interest of the public generally or any person or class of persons in particular," ${ }^{195}$ it may grant the injunction sought by the Commission.

Whether or not section 147 of the Securities Act could provide a basis for injunction proceedings in respect of violations of the proxy provisions is not entirely clear. As a matter of general policy, it could be argued that whereas the Commission's mandate manifestly extends to protecting the public against fraudulent practices in connection with the issuance of or trading in shares, it is quite another matter to claim that that authority extends to intervention in the internal affairs of corporations. Yet it is possible to construct an argument to warrant just such intervention. It is a tortuous argument, and, although based on the language of the Securities Act, it is not advanced here with any great confidence.

So far as non-Alberta companies offering shares to the public in Alberta, or listed on the Calgary exchange are concerned, injunctive relief at the suit of the Commission in respect of proxy violations might be based on section 147 (1). These companies are subject to the proxy requirements of the Securities Act, and the Commission might rely upon either section 147 (1) (b) or (c). In the former case, if the company has failed to honour an undertaking given pursuant to a direction by the Commission under section 106 (1), the direction clearly affects the right of the company to "trade in securities," since if the undertaking is not supplied, no receipt for the prospectus will be issued, and without such a receipt no public offering can lawfully be made. But if the violation is committed by a non-management group, there will be no "direction" to provide a foundation for proceedings under section 147 (1) (b). In this case, recourse must be had to section 147 (1) (c) which, if relevant in this context at all, should be available in respect of management and non-management violations alike.

Two conditions must be satisfied before the Commission may seek an injunction under section 147 (1) (c): first, criminal proceedings or "proceedings in respect of a violation of this Act or the regulations" must have been instituted, and second, the Commission must have formed the opinion that those proceedings "are connected with or arise out of any security or any trade therein or out of any business conducted by that person or company involving securities." The argument here would be that a proxy solicitation is "connected with a security" so that the proceedings in respect of proxy violations will be proceedings connected with a security. So far as the former condition is concerned, "criminal" proceedings will hardly ever be relevant to a proxy violation

194 Alta. Securitles Act, s. 147 (3) (a).

105 Alia. Securities Act, s. 147 (3) (b). 
if, as seems to be the case, the term refers to a proceeding relating to an offence under the Criminal Code. For all practical purposes, therefore, the relevant statutory provision would be section 147 (1) (c) (ii), and the proceedings referred to will be summary conviction proceedings under sections $128 \mathrm{~d}(2), 128 \mathrm{e}(3)$ or $128 \mathrm{e}(4) .^{190}$ This machinery seems uncommonly cumbersome.

The Commission's power to seek an injunction against proxy violations committed by an Alberta company is even less clear. Alberta companies are not subject to the proxy provisions of the Securities Act, ${ }^{107}$ and unless listed for trading on the Calgary exchange or engaged in a public offer through a prospectus filed with the Commission, they are not required to file solicitation material with the Commission. ${ }^{198}$ Section 147 (1) of the Securities Act will not apply to, nor will the Commission be able to obtain injunctions against them.

But suppose that an Alberta company has made a public offering of its shares through a prospectus filed with the Securities Commission, or is listed and traded on the Calgary exchange, and that undertakings have been given as to compliance with the proxy provisions of the Securities Act. Presumably this is sufficient to found proceedings by the Commission under section 147 (1) (b) for a violation of the Commission's "direction" though of course the Commission's power to refuse a prospectus receipt will doubtless be a more effective threat in most cases. But it should be appreciated that it is the power to extract undertakings that is the critical basis for injunctive relief at the instance of the Commission. Here again, however, non-management solicitations in respect of Alberta companies will be beyond the reach of injunction proceedings at the instance of the Commission.

(iv) Enforcement by private civil action.

Both the Companies and Securities Acts are silent on the question whether any private civil rights of action arise to enforce compliance with the proxy legislation. In Charlebois v. Bienvenue, ${ }^{109}$ interlocutory injunctions were granted pending trial to restrain certain persons elected at a meeting in respect of which a misleading information circular had been distributed, from acting as directors. The basis for the decision reached is, however, not completely satisfactory. After holding that the requirements of the Ontario regulations as to the contents of information circulars had not been compiled with,"00 Fraser, J. went on to say that "the defendants were also in breach of duty owed to the company quite apart from the requirements of the Corporations Act. The relationship of directors to a company is fiduciary and to hold an annual meeting and election of directors after sending out a misleading information circular to other shareholders would seem prima

$10 n$ See above, $p .41$. There is a general "offences and penalties" provision in the Securities Act-s. 136. The substantive offences in section 136 are largely duplicated in the penalty provisions of the proxy legislation. The general penalties under section 136 are, however, subject to a procedural limitation set out in section 137 (1), which provides that proceedings under section 136 may only be instituted under the direction or with the consent of the Attorney General.

197 Alta. Securities Act, S. 100 (a) (iii).

198 Alta. Regulations 227/67, (1967), s. 10 (1) (b).

109 (1967) 64 D.L.R. (2d) 683 (Ont.).

200 Id., at 961 . 
facie to be a breach of that duty." ${ }^{201}$ The learned judge then referred to some of the well-known cases on misleading notices of meeting. ${ }^{202}$

The view that the theory of the decision was that there had been a breach of the directors' duty, is confirmed by that part of the judgment in which ${ }^{203}$ Fraser, J. discusses the rule in Foss v. Harbottle, ${ }^{204}$ and makes it clear that he regards the action in Charlebois v. Bienvenue as a "derivative" corporate action to enforce the rights of the company against its defaulting directors. The plaintiffs, then, were appearing in a representative capacity.

This theory is doubtless adequate to deal with the facts of Charlebois v. Bienvenue itself. The defendants were directors of the company subject to the general fiduciary duties described by the judge; but in Fraser, J.'s view a sufficient case of fraud had been made out to preclude the operation of the rule in Foss v. Harbottle. But this approach does not provide any clear answers to the questions whether, and if so in what circumstances, a civil right of action will arise from a violation of the proxy provisions. Suppose that the plaintiff in Charlebois v. Bienvenue had failed to establish that "constructive fraud" which in the learned judge's view was sufficient to oust the rule in Foss v. Harbottle. Would that have prevented them from complaining of a non-solicitation or a misleading solicitation? Suppose that the information circular had merely failed to give the required information about the revocability of the proxy. It would surely require some manipulation to bring this omission within the rubric of a breach of fiduciary duties of directors.

But assume, arguendo, that this omission could be treated as a breach of duty. Fraser, J. apparently took the view that the duty in question existed independently of the proxy legislation, which merely particularized it. ${ }^{205}$ If this is correct, would the majority of shareholders be permitted to ratify the irregularity, so as to preclude any complaint? This, indeed, was precisely the question raised by the defendants' motion to dismiss in Charlebois v. Bienvenue. Fraser, J. avoided the problem by finding that there had been "constructive fraud" but unless his judgment is to be taken as authority for the view that any non-compliance with the proxy legislation is constructive fraud, there will still be cases in which a shareholder will have no locus standi to complain of a violation of the statutory provisions. This would not be a completely untenable view. It could be plausibly argued that there are cases-the omission to provide information as to revocability might be one-in which the imposition of the statutory penalty would be a sufficient sanction, and that in the absence of serious prejudice to those whose proxies were solicited, no case for relief is made out. This would be a sort of de minimis argument. To draw the line on the basis of "ratifiability," however, would be undesirable, for that has proved to be a notoriously difficult and elusive test to apply in company law. ${ }^{200}$

\footnotetext{
201 (1967) 64 D.L.R. (2d) 683 at 692.

202 Baillie v. Oriental Telephone \& Electric Co. Ltd. [1915] 1 Ch 503: Garvie v. Axmith (1962) 31 D.L.R. (2d) 65. Mr. Justice Fraser also found that there had not been a proper quorum at the meeting.

203 (1967) 64 D.L.R. (2d) 683 at $693-700$.

204 (1843) 2 Hare 461.

205 (1967) 64 D.L.R. (2d) 683 at 692 . Cf. O'Connor v. S. P. Bray Ltd. (1936) 56 C. L. R. 464 at 478, per Dixon. J. (H.C. of Aust)

$200 \mathrm{Cf}$ Hogg v. Cramphorn [1966] 3 All E.R. 420; Bamford v. Bamford [1968] 2 All E.R. 655 (Ch.D.).
} 
Moreover, it is by no means clear that ratification is relevant to breaches of statutory obligation. Further, the "breach - of - pre-existing duty" theory will not ordinarily assist someone who wishes to complain of a non-management solicitation which violates the proxy legislation, for non-management groups who have taken no part in summoning a meeting ${ }^{207}$ will not generally be under fiduciary obligations. In this case, some other theory must be found.

The simplest approach would be to argue that the proxy legislation itself confers a private right of action by implication. Some writers have asserted that every member of a company has personal standing to enforce rights derived from the Companies Act or the general law, ${ }^{208}$ and if this proposition is sound it would afford a sufficient foundation for proceedings. While there undoubtedly are cases in which provisions of the Companies Acts have been held to provide private remedies, ${ }^{200}$ the proposition as stated is far too broad to be serviceable. There is a well-known principle of statutory interpretation that where a statute creates an offence, and defines particular remedies against persons committing that offence, the party injured is prima facie confined to the remedy prescribed in the statute. ${ }^{210}$ Invariably, this proposition is qualified by the statement that the statute as a whole must be examined "with a view to determine whether it is part of the scheme of the legislation to create, for the benefit of individuals, rights enforceable by action," ${ }^{111}$ and it has been said that "it is easier to hold that a right of action has been given to a person, whom upon a fair construction of the Act, the legislature intended to protect."212

The difficulty in these cases has been succinctly described by an eminent Australian judge in the following way: ${ }^{213}$

The legislature has in fact expressed no intention upon the subject, and an interpretation of the statute, according to ordinary canons of construction, will rarely yield a necessary implication positively giving a civil remedy. As an examination of the decided cases will show, an intention to give or not to give, a private right has more often than not been ascribed to the legislature as a result of presumptions or by reference to matters governing the policy of the provision rather than the meaning of the instrument. Sometimes it almost appears that a complexion is given to the statute upon very general considerations without the authority of any general rule of law or the application of any definite rule of construction.

In the absence of any compelling rule of law requiring a different conclusion, I suggest that a direct private right of action based upon the statute itself ought to be acknowledged. The legislation recognizes

207 See note 50, above.

208 E.g., Beck, supra, n. 16, at 587.

200 In Cooper v. Premier Trust Co., supra, n. 56, for example, the Ontario Court of Appeal granted a mandatory order to enforce the right of the shareholder under section 109 of the Canada Corporations Act, R.S.C. 1952, c. 53, to inspect the company's books.

210 Transport Oil Ltd. v. Imperial Oil Ltd. [1935] 2 D.L.R. 500 (Ont. C.A.), affirming [1935] 1 D.L.R. 751; Orpen v. Roberts [1925] 1 D.L.R. 1101; Sims v. Kelly (1890) O.R. 291.

211 Orpen v. Roberts [1925] 1 D.L.R. 1101, at 1106.

212 Craies, Statute Law (6 ed. 1963) 249. But the learned editor of this authoritative text adds: "but the question of action or no action cannot, however, be solved by asking whether the statute was or was not enacted for the benefit of any particular class or individual, for the duty imposed by the statute may be of such paramount importance that it is owed to the public at large." Id. Somewhat helplessly, the learned editor concludes: "the court sometimes decides the question in one way and sometimes in another. Id.

213 O'Connor v. S. P. Bray Ltd. (1936) 56 C.L.R. 464 at 478. 
the special character of the relationship between the member and his nominee, and the consequences of that special character: ${ }^{214}$

Unlike most agencies in which the principal gives instructions to the agent, the agent holding a corporate proxy has far more information concerning the issues involved than his principal-the shareholder-and as a practical matter determines the matter in respect to which the agency will be carried out. This distortion of the ordinary principal-agent relation, a distortion inherent in the modern corporate structure, made possible the abuses which the legislation was designed to correct.

To this end, the new provisions limit the scope of the nominee's authority, and define the conditions in which it may be exercised by requiring disclosure of its extent and the provision of information thought relevant to the rational exercise of the shareholders' franchise. It would be a curious result indeed if this elaborate system of regulation could be set at nought by anyone wishing to pay a price of one thousand dollars.

Moreover, if a private right of action were denied, the result may well be to place the shareholder in a worse position than he was prior to the enactment of the new legislation. The common law always recognized inadequate disclosure as a ground for setting aside the decisions of company meetings. ${ }^{215}$ While it is doubtless true that the new legislation requires a different and much broader disclosure, this must surely be taken as a legislative determination of the minimum content of adequacy in cases where proxies are solicited. To argue now that because of the legislation the civil remedy previously available has been superseded by a "criminal" penalty, is surely perverse. It is especially important that the private remedy be recognized in view of the doubts surrounding the power of the Securities Commission to intervene.

The advantage of recognizing a private right of action based upon the statutory provisions is that it provides a consistent basis for proceedings in respect of both management and non-management violations. Moreover, it avoids the difficulty of distinguishing between significant and insignificant violations on the grounds of ratifiability. In the majority of cases the application will be for some form of equitable relief, generally an injunction or declaration, in respect of which the court will have a discretion.

The thrust of the argument advanced here is that every shareholder, as a member of the class sought to be protected by the legislation, has a direct personal right, based upon the statute, to complain of noncompliance with its provisions. But is there also a corporate cause of action, or is the private shareholder's proceeding "a one-way street, unavailable to management"?216 In Charlebois v. Bienvenue, ${ }^{21 i}$ as we have seen, the existence of a corporate cause of action was impliedly acknowledged, though for reasons which, as has been suggested, are unsatisfactory. Some of the earlier American cases took the view that if the company were permitted to sue a non-management group in respect of a proxy solicitation, management would be provided with a weapon with which to harass its opponents. ${ }^{218}$ This view was strongly

214 Von Mehren \& MacCarroll, The Proxy Rules: A Case Study in the Administrative Porcess, 29 Law \& C.P. 729 (1964). See also Kimber Report, supra, n. 7, para. 6.17-24. 215 See, e.8. the authorities cited in note 202 , above.

2162 Loss, supra, n. 9 at 948.

217 E. G. Howard v. Furst 238 F (2d) 790 (2d Cir. 1956). See 2 Loss, supra, n. 9 at 950. 
criticized, ${ }^{210}$ however, and in J. I. Case Co. v. Borak, ${ }^{220}$ the United States Supreme Court declared that:

The injury which a stockholder suffers from a corporate action pursuant to a deceptive proxy solicitation ordinarily flows from the damage done the corporation, rather than from the damage inflicted directly upon the stockholder. The damage suffered results not from the deceit practised on him alone but rather from the deceit practised on the stockholders as a group. To hold that derivative actions are not within the sweep of the section would therefore be tantamount to a denial of private relief.

As a matter of principle it must follow from this view, and it has been so held by the United States Second Circuit, 221 that the company itself has a direct right of action to enforce compliance with the proxy legislation, for a plaintiff suing derivatively can have no greater right than the corporation he claims to represent.

\section{CONCLUSIONS}

Whether or not the new legislation represents the notable step forward in company law that some have apparently thought depends upon the purposes it is seen as serving. Nobody reading the Kimber Report can fail to be struck by the concern for wider and more frequent periodic reporting of relevant corporate information that pervades that document. The proxy legislation reflects that concern, and, seen purely as a scheme for more elaborate disclosure, it is doubtless reasonably workmanlike.

The principal mechanical deficiency in the legislation lies, as has been shown, in its enforcement provisions. This, it is suggested, is the result of an underlying ambiguity as to the purposes for which disclosure is required. The Kimber Committee thought wider disclosure was desirable because it contributes to the containment of fraud. More important, however, as the Committee pointed out, it permits the making of better individual investment decisions, the cumulative effect of which is to enable the capital market "to assure the optimum allocation of financial resources in the economy, to permit maximum mobility and transferability of those resources, and to provide facilities for a continuing valuation of financial assets."222 It was clearly the public interest in information about corporate affairs that the Kimber Committee considered critical.

Yet although the ultimate justification for improved disclosure is its importance in the public interest, the legislation itself is curiously fainthearted in pressing this claim. First, it embodies a very restricted view of the scope of the public interest-no information need be disclosed that is not of direct interest to investors or, possibly, creditors. The possibility of applying other criteria which might lead to other kinds of disclosure ${ }^{223}$ is nowhere acknowledged in the legislation nor, apparently, was it considered by the Kimber Committee. Second, while the legislation does little to ensure that appropriate remedial machinery is available, it seems clearly to embody the assumption that the protection of the public interest is a hoped-for by-product of the

2192 Loss, supra, n. 9, at 950.

220377 U.S. 426, 432 (1964).

221 Studebaker Corporation v. Gittlin 360 F. (2d) 692 at 695 (2d Cir. 1966). The court in this case abandoned the view it had taken in Howard v. Furst 238 F. (2d) 790 (2d Cir. 1956).

222 Report, supra, n. 7, para. 1.06

228 Cf. Wedderburn, Company Law Reform, Fablan Tract 363 (1865). 
protection of members' interests. The proxy system has been adopted as a means to the end of securing greater shareholder control of management.

It may be that the proxy system will have a significant effect upon the ability of shareholders to control management. If so, it may perhaps be fair to regard it as "the salvation of the modern corporate system." Yet there are both legal and factual grounds for doubting that this will happen. The proxy system itself does nothing to affect the legal distribution of power in the modern corporation under which, in most companies, substantially all power is vested in the hands of management. ${ }^{22+}$ But even if it did, it is by no means evident that shareholders would be able, or indeed willing, to exercise effectively the power vested in them in law. First, they are too widely scattered.225 Second, there may well be perfectly good reasons for individual shareholders to conclude that it is not worth the time and trouble involved to vote, let alone organize other shareholders. They may fairly decide that they prefer to rely upon the resources of large shareholders, such as institutional investors, and it is possible that to the latter the proxy system will prove a boon. But there is little evidence of institutional investors preferring to fight rather than switch their investments. And the individual shareholder might well conclude that it is easier. for him to sell his shares than organize a proxy fight..226

A perceptive American observer, commenting on experience under comparable legislation in the United States, suggests that all that has happened is "a considerable amount of publicity and much smoother corporate public relations, but little else." responsibility by re-inforcing membership rights is little more than an attempt to remould twentieth century reality to conform to an eighteenth century theory about the proprietary nature of the shareholder's interest. If there is any substance in this view, all the assumptions that currently dominate thinking about company law must be comprehensively re-examined, unless reform is to consist merely of a series of elegant arabesques. Good company law reform is difficult and expensive. Its requirements are not satisfied by the sort of piece-meal borrowing that the proxy legislation in Alberta represents.

$224 \mathrm{Cf}$, generally Slutsky, Relationship between the Board of Directors and the Shareholders in General Meeting, (1968) 3 U.B.C.L. Rev. 81.

225 This proposition has never been fully documented in Canada, although some limited evidence about share ownership may be found in the Brief of the Montreal Stock Exchange to the Porter Royal Commission on Banking and Finance (1964). Exchange to the Porter Royal Commission on Banking and Finance (1964). Paradoxically, one of the considerations which motivated the Kimber Committee
was a desire to see Canadians invest in equities rather than save. Report, supra, n. 7, para. 1.13. There is no reason to believe that Canadian trends in share ownership differ significantly from those in other countries. Even where, as in England, geographical dispersion is relatively unimportant the record of shareholder activity is unimpressive. See Kimber, The Ensnared Shareholder Ch. VII (1965).

226 Cf. Benerally, Manne, Some Theoretical Aspects of Share Vioting, (1964) 64 Col. L. Rev. 1427, 1441-2.

227 Hetherington, Fact and Legal Theory: Shareholders, Manager, and Corporate Responsibility, (1969) 21 Stanford L. Rev. 248, 252. 